Cornell Law Library

Scholarship@Cornell Law: A Digital Repository

Cornell Law Faculty Publications

Faculty Scholarship

$12-1-1982$

\title{
The Concept of Property in Private and Constitutional Law: The Ideology of the Scientific Turn in Legal Analysis
}

Gregory S. Alexander

Cornell Law School,gsa9@cornell.edu

Follow this and additional works at: http://scholarship.law.cornell.edu/facpub

Part of the Constitutional Law Commons, Legal History, Theory and Process Commons, and the Property Law and Real Estate Commons

\section{Recommended Citation}

Alexander, Gregory S., "The Concept of Property in Private and Constitutional Law: The Ideology of the Scientific Turn in Legal Analysis" (1982). Cornell Law Faculty Publications. Paper 471.

http://scholarship.law.cornell.edu/facpub/471

This Article is brought to you for free and open access by the Faculty Scholarship at Scholarship@Cornell Law: A Digital Repository. It has been accepted for inclusion in Cornell Law Faculty Publications by an authorized administrator of Scholarship@Cornell Law: A Digital Repository. For more information, please contact jmp8@cornell.edu. 


\section{The Concept of Property in Private and Constitntional Law: The Ideology of the Scientific Turn in Legal Analysis}

\section{Gregory S. Alexander*}

In recent academic writing on the general problem of constitutional protection of property under the takings clause ${ }^{1}$ and due process clauses, ${ }^{2}$ a mode of analysis has emerged that is evidently different from the convention.al analysis of constitutional property claims. In general terms, this new mode is characterized by an effort to analyze claims on an openly teleological and systematic basis. To be sure, this mode is not exclusively of recent origin. ${ }^{3}$ But it is a discernible trend in the body of scholarship that discusses constitutional protection of property in the context of previously unfamiliar sorts of private economic interests. Charles Reich's famous paper, "The New Property," is the wellspring for this phase of scholarship on constitutional property. Subsequent writings by Frank Michelman, ${ }^{5}$ Joseph Sax,${ }^{6}$ and others ${ }^{7}$ have contributed to the trend with respect both to procedural protection under the due process clause and to substantive protection through compensation.

Most observers who have commented upon the development of this new mode of analysis have seen a radical discontinuity between its teleological

*Visiting Professor of Law, University of California, Los Angeles; Associate Professor of Law, University of Georgia. B.A. 1970, University of Illinois at Urbana-Champaign; J.D. 1973, Northwestern University.

Thanks are due to various colleagues for their generous readings. I am especially indebted to Robert Brussack, Kenneth Karst, Thomas Horawetz, Gary Schwartz, Dick Wellman, and Michael Wells.

1. U.S. Const. amcnd. V, cl. 4 ("'nor shall private property be taken for public use, without just compensation"').

2. U.S. Const. amend. XIV,$\S 1$ ("nor shall any state deprive any person of life, liberty, or property, without due process of law"); U.S. Const. amend. V., cl. 3 ("nor be deprived of life, liberty, or property, without due process of law").

3. Traces of it can be found in Allison Dunham's writing, for example. See, e.g., Dunham, Griggs v. Allegheny County in Perspective: Thirty Years of Supreme Court Expropriation Law, 1962 S. Ct. Rev. 63.

4. Reich, The New Property, 73 Yale L.J. 733 (1964).

5. Michelman, Formal and Associational Aims in Procedural Due Process, in Nomos XVI11, Due Process 126 (J. Pennock \& J. Chapman eds. 1977) [hereinafter cited as Michelman, Formal Aims]; Michelman, Property, Utility, and Fairness: Comments on the Ethical Foundations of "Just Compensation" Law, 80 Harv. L. Rev. 1165 (1967) [hereinafter cited as Michelman, Property, Utility, and Fairness].

6. Sax, Takings, Private Property and Public Rights, 81 Yale L.J. 149 (1971) [hereinafter cited as Sax, Takings]; Sax, Takings and the Police Power, 74 Yale L.J. 36 (1964) [hereinafter cited as Sax, Police Power].

7. See, e.g., Berger, A Policy Analysis of the Taking Problem, 49 N.Y.U. L. Rev. 165 (1974); Tushnet, The Newer Property: Suggestion for the Revival of Substantive Due Process, 
approach and the analysis traditionally applied by courts to cases under the takings and due process clauses. In this Article I shall argue that, on the contrary, the new mode of analysis may be viewed as a fundamentally reactionary response to the challenge presented to liberal ideology by the rise of the social welfare state. The methodological differences between the old and new analyses are real, but exist at only the most superficial level. At a deeper level methodological continuity may be discerned. More importantly, at the ideological level the new analysis represents no break at all with the traditional mode. The apparent rise of the new mode of analysis results from the need of liberal legal theory to revise the traditional conceptual apparatus of the property clauses of the Constitution, derived from traditional private-law notions, in order to continue to serve the ideological premises of legal doctrines aimed at protecting private property interests.

My account of the rise of the teleological mode will be oriented around Professor Bruce Ackerman's book, Private Property and the Constitution, ${ }^{8}$ which is perhaps the most ambitious attempt to date to explain the nature of, and impetus for, the new mode of analysis. Professor Ackerman illuminatingly linked traditional constitutional doctrine, particularly under the takings clause, to the layperson's conception of property and the courts' desire to develop legal norms that would support dominant social expectations. These observations will provide a starting point for my analysis, but Professor Ackerman's thesis, I will argue, is as revealing in its errors as in its insights. In the process of elaborating his initial insight he falls into mistakes, and the nature of these mistakes provides support for my own thesis regarding the rise of the new analysis.

Using the takings clause as the vehicle for his discussion, Ackerman argues that the general trend towards analysis based on comprehensive value systems has emerged in reaction to the inability of the orthodox mode of legal analysis, which builds upon ordinary thought and is thus not systematic in the scientific sense, to produce determinate results in the most difficult modern legal disputes. Increased state activism has precipitated the appearance of claims to constitutional protection under the takings and due process clauses, claims involving interests whose characteristics render "ordinary" legal analysis inadequate as a means to evaluate them. This methodological dead-end has forced modern legal scholars to develop scientific analyses that collectively represent the teleological mode. The traditional mode is now under great pressure from the teleological mode, whose analytic power has not been affected by these social and political changes precisely because it is scientific and systematic. This interpretation has an implicit normativc image. Although Ackerman acknowledges that teleological analysis is attended with serious difficulties, he considers it to be preferable because of its superior analytic power. ${ }^{9}$

1975 S. Ct. Rev. 261; Comment, Entitlement, Enjoyment, and Due Process of Law, 1974 Duke L.J. 89.

8. B. Ackerman, Private Property and the Constitution (1977).

9. Id. at 166. There is some disagreement in the earlier reviews over whether Ackerman's account is purely descriptive and explanatory or whether he implicitly expresses his preference for 
I shall argue that Ackerman's explanation rests on an inaccurate account of the layperson's conception of property. By allowing Ackerman to focus exclusively on methodology, this erroneous model of ordinary thought permits him inaccurately to portray as both necessary and politically neutral the conceptual revisionism that constitutional property law is undergoing. In fact, it is neither necessitated by a purely methodological crisis nor politically neutral. By making the conceptual revision seem necessary and even inevitable, Ackerman's account hides the contingency and subjectivity of the process of drawing lines between "property" and "nonproperty." 10 Ackerman's thesis thus exhibits on the level of metatheory the same tendency that the teleological scholars themselves show on the level of theory: the continual denial in legal scholarship of the conflict in liberal legal theory between the asserted objectivity of legal doctrines and the unavoidable subjectivity of their bases. ${ }^{11}$

Though most of the commentary on Professor Ackerman's work has dealt with his thesis in the context of compensation litigation growing out of land use and environmental regulation, ${ }^{12}$ I shall discuss his thesis primarily as it relates to private interests in wealth that derive directly from the government, such as welfare benefits. I do so not only because relatively little attention has been devoted to this aspect of his hypothesis and because he has subsequently emphasized its importance, ${ }^{13}$ but also because the growth of the welfare state seems to me to pose a greater potential threat to dominant liberal ideology than that posed by increased government regulation of the use of private resources. In this context, the methodological problem of traditional analysis is exemplified, according to Ackerman, by Flemming $v$. Nestor. ${ }^{14}$ The

scientific policymaking as the superior mode of legal analysis. Richard Epstein reads Ackerman as I do, interpreting Ackerman to say that "Scientific Policymaking" (to use Ackerman's terms) is the "solution" to the "dead end" in which "Ordinary Observing" now finds itself. Epstein, The Next Generation of Legal Scholarship?, 30 Stan. L. Rev. 635, 639-40 (1978) (reviewing B. Ackerman, Private Property and the Constitution (1977)). Accord Tushnet, Truth, Justice, and The American Way: An Interpretation of Public Law Scholarship in the Seventies, 57 Tex. L. Rev. 1307, 1346 n.167 (1979). James Krier and Gary Schwartz, however, express some hesitancy about this reading, although they concede that Ackerman does intimate his preference for Scientific Policymaking. Krier \& Schwartz, Talking about Taking, 87 Yale L.J. 1295, 1311 n.84 (1978) (reviewing B. Ackerman, Private Property and the Constitution (1977)). The point is not simply that Ackerman likes Scientific Policymaking more than he does Ordinary Observing but that $\mathrm{h} \rightarrow$ regards the latter as analytically inadequate. B. Ackerman, supra note 8 , at 166 . For a discussion of Áckerman's terms, see infra Section IC.

10. In recent years there has appeared a small but quite interesting literature on the subjective nature of the process by which legal analysis creates artificial entities, pretending that they had a priori content. See J. Vining, Legal Identity, The Coming of Age of Public Law (1978); Katz, Studies in Boundary Theory: Three Essays in Adjudication and Politics, 28 Buffalo L. Rev. 383 (1979). An early example, in the tradition of realism, of this theme is the late Alexander Nekam's The Personality Conception of the Legal Entity (1938).

11. See Tushnet, Legal Scholarship: Its Causes and Cure, 90 Yale L.J. 1205, 1206 (1981).

12. See, e.g., Soper, On the Relevance of Philosophy to Law: Reflections on Ackerman's Private Property and the Constitution, 79 Colum. L. Rev. 44 (1979); Epstein, supra note 9; Kornhauser, Book Review, 52 N.Y.U. L. Rev. 1461 (1977); Krier \& Schwartz, supra note 9.

13. Ackerman, Four Questions for Legal Theory, in Nomos XXII, Property 351, 362-63 (J. Pennock \& J. Chapman eds. 1980) ("My aim in Private Property was to demonstrate that the idea of 'new' property could not be dismissed as some more chitchat from the leftist fringe of the profession; instead, it represents a straightforward application of a form of property talk with which the profession is entirely familiar.").

14. 363 U.S. 603 (1960). 
solution to the problem may be found, in Ackerman's view, in Charles Reich's famous argument that interests in government largesse should be treated for constitutional purposes as the "new property." 15 The theory of the "new property" represents, in Ackerman's view, a methodological reaction to a methodological problem.

My goal in this Article is to explain the reasons for the emergence of the new mode of analysis. Before such an explanation can be attempted, it is necessary to undertake the complex task of describing the similarities and differences between the two modes. Part I provides an overview of the two approaches-especially as they differ in their treatment of the problem of entitlements-and will briefly explain the methodological distinctions that Professor Ackerman draws between them. In Part II, I argue that Ackerman's methodological distinctions are based on an implausible account of the layperson's conception of property. I suggest that ordinary expectations exhibit a conceptual structure sufficiently complex to permit recognition of a much broader range of interests than Professor Ackerman's "social property." Included in this group of abstract interests are some, but not all, nonpossessory interests. I describe the basis on which ordinary thinking distinguishes between property and nonproperty in terms of a deeply rooted cultural predisposition to treat as nonproperty those interests that are subject to a power held by another person to extinguish all possibility of present or future possession. In Part III, I trace the same notion through private law doctrines distinguishing between property and nonproperty. The tendency to view sub. ordinated interests as nonproperty is evident in several common-law doctrines. I discuss in Part IV the extension of this tendency from the common-law setting to the question of constitutional protection of a new category of claiminterests in Flemming $v$. Nestor. The Flemming Court's refusal to hold interests in future Social Security benefits protectible was not the consequence of a methodology rendered impotent by changes in the forms of social wealth, but the product of a widely shared notion that is not captured by any of Ackerman's conceptual categories. My objective is neither to justify the decision in Flemming nor to suggest that ordinary habits of thought are a normatively adequate basis upon which to base decisions about the protectibility of individual interests. Rather my aim is to indicate how the concept of property implicit in Flemming might be explained as consistent at an abstract level with ordinary habits of thought, which would fundamentally undercut the claim of analytical superiority of a scientific conception of property. Then, in Part V, I explain how Ackerman believes his methodological distinction accounts for the emergence of the new mode of analysis, and I offer an alternative explanation of the conceptual revision of property in the constitutional setting. This account emphasizes the ideological reasons for the recent shift to the so-called scientific conception of property, such as that found in arguments about the "new property."

15. Reich, supra note 4. See also Lynn, Legal and Economic Implications of the Emergence of Quasi-Public Wealth, 65 Yale L.J. 786 (1956) (an article that anticipated a part of Reich's "New Property" - and that deserves more credit than it has received). 
My ultimate objective is to counteract the impression left by Ackerman's account that the conceptual revisionism at work in modern constitutional property theory is analogous to scientific revolutions, where changes in paradigms of thought are precipitated by external events that lead to methodological failures of the established mode. Such an account makes the change appear necessary and neutral, hiding the ideological function of the conceptual change underway. This Article attempts to expose that function by peeling away the pretense of objectivity in the scientific mode of legal analysis.

\section{Two Modes of Legal Analysis}

This section will provide a general introduction to the approaches taken by the old and new modes of analysis, emphasizing their different ways of handling the problem of entitlements. 1 will also set out the part of Ackerman's thesis that merely describes the supposed differences between the two modes. My own alternative description will be given in Parts 1I-IV; discussion of both my own and Ackerman's explanations for the emergence of the new mode will be taken up in Part V.

\section{A. The Emergence of a New Mode of Constitutional Property Analysis}

Until recently, when a claim was made to protection of a private interest under the takings clause or under that part of the due process clause that guards against deprivations of "property," the claim would be analyzed by asking whether a series of conditions, necessary and sufficient to relief, were met. The threshold question was whether the interest constituted property. The textual reference to "property" in both clauses seemed to demand, as a prerequisite to constitutional protection, that the character of the claimant's interest as "property" first be established; ${ }^{16}$ it was assumed that not every subjectively held interest was property. Only if the interest involved was determined to be property did the analysis proceed to the second question posed by the texts of the fifth and fourteenth amendments. Under the fifth amendment takings clause the question was: Has the property interest been "taken" by the State? Under the fifth or fourteenth amendment due process clause the question was: Has the claimant been "deprived" of his property interest? Just as not every subjectively held interest constituted property, not every governmental action causing subjective harm to property constituted a "taking" or a "deprivation." Those concepts, like that of "property," performed a screening function under this "conceptual" mode of analysis. The final questions ${ }^{17}$-Has the claimant been denied "due process of law"? What

16. This has probably been more true of takings analysis than due process analysis. One commentator has observed that prior to Board of Regents v. Roth, 408 U.S. 564 (1972), the Supreme Court's approach to "liberty" and "property" for procedural due process purposes "amounted to taking the words 'life, liberty, or property,' as a unitary concept embracing all interests valued by sensible men." Monaghan, Of "Liberty" and "Property," 62 Cornell L. Rev. 405, 409 (1977).

17. Under the takings clause, there was also the intermediate question whether the taking was for "public use," inviting inquiry into justifications for the State's taking. 
is the measure of "just compensation" to which he is entitled? - would not be reached unless a "taking" or "deprivation" of "property" had been established.

Using this traditional mode of analysis, the Supreme Court held in Flemming $v$. Nestor ${ }^{18}$ that a provision of the Social Security Act ${ }^{10}$ that terminated old-age benefits to aliens deported for any of several specified reasons did not result in an unconstitutional deprivation of property from an individual who had been receiving such benefits until his deportation. Nestor had immigrated to the United States from Bulgaria in 1913 and had begun receiving old-age benefits in 1955. He was deported in 1956 for having been a member of the Communist Party from 1933 to 1939. His benefits were terminated shortly after his deportation because membership in this group was one of the statutorily specified grounds for termination. The Court concluded that this statute did not violate the due process clause of the fifth amendment because Nestor's interest in Social Security benefits was not an "accrued property right" and was therefore not protectible against the federal government's substantive encroachment. Rather, it was a weaker interest that had only "sufficient substance to fall within the protection from arbitrary governmental action," 20 which the Court found was not involved.

The holding that Social Security benefits are not an accrued property right was a principal factor motivating Charles Reich's development of the theory of the "new property." ${ }^{21}$ Reich advocated treating interests like Nestor's as property for constitutional purposes. He argued that the instrumental reasons that cause the legal system to protect conventional forms of property - chiefly, securing for individuals a zone of safety against external, including governmental, encroachment-have equal force with respect to interest in government largesse.

Reich's theory of the "new property" was the first major instance in entitlement law of the general trend in legal scholarship towards a new and

18. 363 U.S. 603 (1960).

19. 42 U.S.C. $\S 402(\mathrm{n})(1976)$.

20. 363 U.S. at 611 . This conclusion creates uncertainty about the real meaning of the majority's conclusion in Part I that Nestor "has not such a right in benefit payments [to makel every defeasance of 'accrued' interests violative of the Due Process Clause of the Fifth Amendment." 1d. As framed in Part 1 , the issue appears to be whether there was a deprivation of property within the meaning of clause 3 of the fifth amendment. After having decided that Nestor had not been deprived of property, the majority opinion in Part Il goes on to consider whether he was deprived of property without due process by arbitrary action. If in Part I the majority was really talking about property within the meaning of clause 3, then there should not be any need to discuss whether Nestor was denied due process, as there was no suggestion of an interest in life or liberty implicated in the government's action. Perhaps, then, Part I of the opinion is really talking about property within the meaning of clause 4 of the fifth amendment, which is the issue to which Justice Black's dissenting opinion is addressed. Part II of the opinion, in which the due process issue is discussed, can thus be explained as assuming that the term "property" as used in clause 4 is broader than in the context of clause 3 and that for clause 4 purposes, Nestor's interest was property. But the majority does not explain why his interest was property even for due process purposes. Perhaps the point of Part 11 is to explain why Nestor was not denied due process rights even assuming, without actually holding, that he had a property interest for due process purposes.

21. Reich, supra note 4 . 
overtly teleological analysis. ${ }^{22}$ This new mode rejects implicitly, if not explicitly, the necessity of facing the property vel non question, ${ }^{23}$ and focuses immediately and exclusively on the concepts of due process and just compensation. Instead of asking first whether the claimant's interest is "property," scholars in the new mode begin their inquiry by considering the requirements of due process and just compensation, and developing a comprehensive theory of the goals that these requirements are meant to achieve. The protectibility of an interest turns solely on its relationship to the moral theory that is imputed to the relevant concepts of due process and just compensation. In avoiding the question of property vel non, the teleological scholar does not merely pass over the initial steps in traditional analysis, and then analyze "due process" and "just compensation" in a manner analogous to traditional analysis of the term "property." The question of property vel non, in the traditional mode, did not explicitly require a substantive theory of the role of private property in contemporary society, but the teleological mode of analysis requires a deep

22. Representative of this scholarship are Professor Frank Michelman's essays on yrocedural due process and the takings clause. In Formal Aims, supra note 5, Michelman argues that the entitlement doctrine, conditioning procedural due process rights on the presence of some entitlement that is rooted in positive law, reflects an exclusively formal conception of the purposes of due process explanatory procedures. That conception, he contends, is significantly undercut by cases in which procedural due process rights have been recognized even though no positive entitlement, of the sort required by Board of Regents v. Roth, 408 U.S. 564 (1972), was involved. Those cases reflect awareness of " 'what everyone knows': that there are values in consultation and interchange with affected individuals quite discrete from the aim of protecting their substantive legal rights-values whose potential in a given situation need not depend on whether any entitlement is at stake." Michelman, Formal Aims, supra note 5, at 147. In these cases, Michelman suggests, one finds the formal conception replaced by, or at least supplemented with, the conception of due process as furthering communitarian values of revelation and participation. Under this associational theory of due process the presence or absence of positivistic entitlements is irrelevant, for procedural rights are no longer merely pendent on substantive rights. Only our formalistic habits of mind perpetuate the need for finding (and in some instances, fabricating) entitlements. Michelman is evidently frustrated with the persistence of this formalist constraint, even if in fact it commands nothing more than lip service, and he is sympathetic with the associational theory of due process values. He stops short of unequivocally endorsing such a theory, however, because he is skeptical whether judicial imposition of procedural duties on officials will meaningfully serve nonformal, communitarian values. Id. at 133-34, 152.

A similar move toward morally based analysis that alters the role of property is taken in Michelman's paper on the takings problem, Property, Utility, and Fairness, supra note 5 . He does not analyze takings cases in terms of problems in determining whether affected interests were "property" or whether the government action in question constituted a "taking." His approach is more comprehensive, seeking to construct a coherent moral justification for the compensation requirement. Specifically, he analyzes the compensation principle from utilitarian/efficiency and fairness perspectives, using John Rawls's conception of fairness as the model for his nonutilitarian account.

Other examples of scholarship of this sort include Berger, supra note 7, and Sax, Police Power, supra note 6 , both dealing with the compensation requirement, and, in the context of procedural due process analysis, L. Tribe, American Constitutional Law 501-06, 522-32 (1978), and Tushnet, supra note 7 .

23. The rejection of the need to ask this question is characteristic of recent attacks on the doctrine-which Michelman refers to as the notion of "entitlement-triggers"-that statutory entitlements are a prerequisite to procedural due process protection. Michelman, Formal Aims, supra note 5, at 134-37. An especially clear example of this is Note, supra note 7, at 107-I1, $114-16,118-20$. 
inquiry into normative moral theory in order to specify the content of the critical concepts of due process and just compensation. The teleological mode of analysis, then, is distinguished from the traditional mode by the central role the new mode assigns to the concepts of due process and just compensation, and by its functional approach to these concepts.

To be sure, not all of the teleological theorists endorse the same substantive ethics that Reich does, and several theories compete for recognition as the basis of these concepts. One theory of the compensation requirement is that its purpose is to protect individuals against government-compelled wealth redistributions that have the effect of exploiting a few individuals for the sake of many. Frank Michelman's famous study of the ethical basis of the just compensation requirement reflects such a view. ${ }^{24}$ Another moral theory popular among teleological scholars at present is utilitarianism. The utilitarian believes the central purpose of the compensation requirement to be the minimization of the social costs of the government action in question. For utilitarians, the protectibility of any given interest turns on an analysis of the relevant costs and efficiency gains of the questioned measure. An early example of this view is Professor Allison Dunham's study of Supreme Court takings decisions. ${ }^{25}$ Discussing several nineteenth century cases dealing with the question of compensation to landowners whose interests were injured by the operation of adjacent elevated railways, he argued:

The propensity of property law to pigeonhole everything into historical categories led to a characterization of this right [of the land owners] as an easement of light, air, and view on the streets. But the basic question was whether the cost that the governmental activity imposed on others by reason of their propinquity should be borne by the public or by those injured..$^{26}$

But despite these differences, scholars in the new mode agree that an interest's protectibility is ultimately determined not by its status as property or nonproperty, but by its relation to the theory of substantive values attributed to the concepts of just compensation or due process.

\section{B. The Nature of the New Approach}

Although Dunham and Reich were clearly writing within the new mode, their arguments may not seem dramatically unfamiliar to contemporary lawyers. The utilitarian analysis that developed after Dunham, however, is strikingly different from the analysis most lawyers are used to, and adopting this new utilitarian analysis would result in a "very considerable expansion"27 of takings clause protection from which recipients of government largesse would

24. Michelman, Property, Utility, and Fairness, supra note 5.

25. Dunham, supra note 3 .

26. Id. at 88 .

27. B. Ackerman, supra note 8 , at 69 . 
benefit mightily. Thus, a brief description of the way in which a utilitarian would analyze the problem presented in Flemming may clarify the nature of the change the new mode represents. ${ }^{28}$

From the utilitarian point of view, the provision for just compensation is aimed not so much at assuring that compensation is paid to individuals whose property interests are extinguished by the state as at facilitating efficient resource allocation. The real issue is not whether $A$ 's "property" was "taken" by the state as a result of its action but whether the government action in question is efficient and thus should be encouraged, and if it should be, which social group "can bear the burden extended by a new legislative decision with the smallest loss in overall utility." ${ }^{29}$ The utilitarian would regard as prima facie desirable a governmental measure that is attended by positive efficiency gains. These gains represent the excess of benefits produced by the measure over the loss incurred as a result of it, benefits being measured by the amount which potential beneficiaries of the action would be willing to pay for it and losses being measured by the amount that potential losers would demand in return for their approval of the action. ${ }^{30}$

But the fact that an action would produce positive efficiency gains indicates only that the measure is rational and thus prima facie desirable. Other costs, not taken into account by the calculation of efficiency gains, may be incurred. If no compensation is paid, certain so-called indirect costs may result: uncertainty may be produced among individuals potentially affected by future government action, and this uncertainty may lead them to take economically inefficient steps to protect themselves against this risk; furthermore, the individuals affected by the regulation and even the community as a whole may come to question the fairness of government activities, leading to general disaffection with existing social institutions. ${ }^{31}$ These indirect costs may be avoided, but only by payment of compensation to those disadvantaged by the measure; such payments, and the cost of processing claims for them, are referred to as "process costs."

Thus, a governmental redistribution of resources in the pursuit of efficiency will incur either the indirect costs of uncertainty and disaffection, or the costs of processing compensation claims. Assuming that both of these costs are lower than efficiency gains, obviously the one that should be borne is the one that is lower. Thus, compensation should be paid if the process costs are lower than net efficiency gains and lower than the sum of the indirect

28. The analysis that follows is based on the "utilitarian" reasoning offered by Michelman, Property, Utility, and Fairness, supra note 5, at 1214-18.

29. B. Ackerman, supra note 8, at 64 .

30. Michelman, Property, Utility, and Fairness, supra note 5, at 1214. (The "willingness-topay" standard is, of course, the accepted economic criterion for value. See R. Posner, Economic Analysis of Law \$1.2, at 10 (2d ed. 1977)).

31. Michelman does not expressly distinguish between these two items of cost, as Ackerman does, but conflates them under the heading of "demoralization costs." The basis for economic concern with forestalling demoralization costs is that demoralization tends to impair the output of goods. 
costs. ${ }^{32}$ But if process costs exceed the sum of the indirect costs but are still lower than net efficiency gains, then compensation should not be required. If process costs exceed efficiency gains, of course, then the governmental action should be rejected, and compensation should be awarded so as to deter the government from taking such action.

Now, applying this theory to specify whether in particular instances compensation should be requircd is problematic because of the difficulty of making the necessary calculations. Nevertheless, it becomes apparent from our thumbnail sketch of utilitarian analysis why Ackerman would suppose that claimants like Nestor would do better under this mode of analysis than under a mode that initially seeks to determine whcther his interest counts as property. The utilitarian would characterize the termination-of-benefits statutes as effecting a redistribution of wealth. The result is that Nestor's case would get past the initial question that was the insuperable impediment to his case in the eyes of the Supreme Court. According to the utilitarian perspective, at Time One, Nestor was receiving monthly cash payments for the system's fund, thereby reducing the size of the fund available for other recipients. At Time Two, after his benefits were terminated following deportation, resources that would otherwise have been directed to Nestor may now be directed at other recipients. This is a redistribution of a valuable interest from Nestor to other participants in the Social Security program. With property removed as a screening device on his claim, the prospects that compensation will be ordered, not to correct a deprivation of property, but to minimize the costs associated with a felicific governmental measure, improve.

Of course, characterizing the benefit-tcrmination statute as effecting a wealth redistribution does not assure that compensation will be paid to Nestor. Whether it will or not depends on the result of calculating the relative magnitude of process, disaffection, and uncertainty costs. But one can point to several factors that appear to strengthen Nestor's claim. Disaffection and uncertainty costs are likely to be high in his case. ${ }^{33}$ The unevenhandedness of the termination of benefits would increase the perception that Nestor's injury was clear and distinct. ${ }^{34}$ Furthermore, Social Security contributors can hardly

32. Ackerman reduces the description to a formula requiring compensation whenever $\mathbf{P}$ is less than U plus D. B. Ackerman, supra note 8, at 48 . For a criticism of this description of utilitarian analysis of the compensation requirement, see Soper, supra note 12, at 47 n.9.

to Law: Reflections on Ackerman's Private Property and the Constitution, 79 Colum. L. Rev. 44, 47 n.9 (1979).

33. I do not mean to say that most laypersons would have objected specifically to the denial of Nestor's Social Security benefits. At the time the administrative decision to terminate his benefits was made, in 1956, I suspect that a very substantial number of people would have supported the decision to deny old-age benefits to a deported former Commuuist. In speaking of the disaffection costs, I am referring to the costs associated with a public perception that the basis for the decision in Nestor's case might be broadened to cast doubt on the security of one's status as a present or future recipient of old-age benefits. The recent debate over Social Security in fact underscores the general perception of the program as contractual in nature, the exact characterization that the majority in Flemming rejected. It is that generalization, then, that leads to disaffection, not Nestor's case specifically.

34. The economic goal in requiring compensation is not to protect against all risks of uncompensated losses but only those risks associated with intolerable disincentive effects. An 
be described as risk-takers, since participation in the system is compulsory, not voluntary. ${ }^{35}$ At the same time, process costs may be manageable, though not trivial. The magnitude of loss is objectively calculable and the range of potential future claimants readily identifiable and limited in number. Thus, it seems likely that, as Ackerman suggests, a utilitarian analysis of Nestor's claim would result in a decision to grant his requested relief. Even if relief were denied, however, the decision would not be explained on the ground that Nestor's interest was not property.

\section{The Ackerman Thesis}

Ackerman's description of the differences between the two modes of legal analysis challenges two commonly held beliefs about contemporary constitutional law. 1t has become common for contemporary legal scholars to claim that "takings law is incoherent, its principles altogether mysterious." ${ }^{38}$ Rejecting this conventional wisdom, Ackerman claims that there is an internal order to the traditional mode, but that many contemporary scholars have been unable to perceive it because they have approached the takings cases from the perspective of the teleological mode. Moreover, when the Supreme Court

attempt to rationalize compensation practices in utilitarian terms assumes that disincentive ef fects are greater where losses are systematically or strategically inflicted by majoritarian exploitation than where losses randomly occur. Michelman, Property, Utility, and Fairness, supra note 5, at 1217. Given this assumption, productive incentives will be more impaired by governmentally compelled redistributions that are perceived as capricious. This means that utilitarian evaluation of claims to compensation will be influenced by the extent to which the claimant's injury is clear and distinct, meaning that he is not simply one of a relatively large group that has suffered in some general way as a result of government action that will ultimately maximize social welfare, but instead has been more or less singled out for sacrifice. Where the injury is of such an order, the redistribution is seen to be "capricious." Such redistributive measures have higher disaffection costs, where by "disaffection" we mean the perception that the justification of the challenged action on utilitarian grounds is suspect even among those persons who are willing to accept governmental redistributions that improve overall social utility. The statute challenged by Nestor is arguably such a measure. It did not merely terminate Social Security benefits of all persons who have been deported for any reason, a measure that might more easily have been justified on strictly utilitarian grounds. It singled out for benefit termination certain classes of deportees. The perceived unevenhandedness of this statute is suggested by the fact that Nestor also attacked it as a bill of attainder. Even the good utilitarian citizen may not see the utilitarian appeal of such a measure.

35. From a utilitarian perspective, compensation may be denied with respect to investments that, when entered into, had been known not to justify expectations of continuing enjoyment. Purchase of a lottery ticket is a clear example of this type of investment. Consensual participation in such activity, in the face of prior warnings of potential collective action, raises no compensation issue because the amount of the investment presumably is discounted by the possibility of future loss. Failure to protect such deliberate speculations is not likely to have significant disincentive effects. But where the investment is compulsory rather than consensual, as in the case of Social Security, arguably this rationale is inapplicable, even though there has been express warning that benefits may be reduced or terminated. Such prior warnings are relevant, if at all, only when actors have an opportunity to avoid the speculation or to negotiate for a lower price that reflects the risk of future loss. The only consequence of prior warning of possible collective action with respect to Social Security benefits is that it may induce participants, if in fact they are aware of the risk, to invest resources in other forms of insurance, insuring against Social Security. Of course, it is questionable whether in fact there has been adequate prior warning of the risk factor of Social Security.

36. B. Ackerman, supra note 8 , at 168 . 
appeared to endorse Reich's theory in procedural due process cases, ${ }^{37}$ commentators interpreted the Court's opinions as a radical departure from all prior legal conceptions of property. ${ }^{38}$ Ackerman, in contrast, discerns an element of continuity between the new analysis and the conceptual apparatus of traditional legal thought.

In order to analyze the two modes, Ackerman classifies legal thought along two axes. One axis concerns legal language; here, the choice is between the Ordinary and the Scientific approaches. The other axis concerns the objectives that the legal system should pursue, and the competing approaches are Observing and Policymaking. These two axes represent variables that are in principle independent, so four combinations are possible. But in practice, only two-Ordinary Observing and Scientific Policymaking-are important. Ackerman identifies the traditional mode with Ordinary Observing, and the teleological mode with Scientific Policymaking.

1. Legal Language. The Ordinary theorist adopts as the legal language the language used by ordinary people. The Scientist, in contrast, attempts to devise a technical language, suited to his needs and often drawn from nonlegal disciplines; ${ }^{39}$ common understandings of legal terms are irrelevant, for those

37. See, e.g., Perry v. Sindermann, 408 U.S. 593 (1972) (teacher's interest in continued employment at a state university); Bell v. Burson, 402 U.S. 535 (1971) (driver's interest in state driver's license); Goldberg v. Kelly, 397 U.S. 254 (1970) (welfare recipient's interest in continued benefits).

One of the critical steps towards recognizing these interests as protectible, was the decline in importance of the so-called right-privilege distinction. See Van Alstyne, The Demise of the RightPrivilege Distinction in Constitutional Law, 81 Harv. L. Rev. 1439 (1968).

38. See L. Tribe, supra note 22, at 514-22; Eisenberg \& Yeazell, The Ordinary and the Extraordinary in Institutional Litigation, 93 Harv. L. Rev. 465, 467 (1980) (Courts have found in constitutions and statutes "heretofore undreamt-of entitlements."). Indeed, some observcrs believed that the Court had failed to explain why these interests were property at all. Note, supra note 7.

39. In a recent paper Ackerman elaborated on the nature of the change in modes of legal analysis:

[Ilt is a mistake to think of the change as a shift from doctrinal analysis to nondoctrinal musings. What is going on is a shift from one kind of doctrinal analysis to another kind of doctrinal analysis. Speaking very broadly, the newer sorts of analysis are characterized by a more self-conscious and elaborate conceptual apparatus than the kinds they are displacing. As a consequence, it is no surprise that the newer doctrinal analysts have been borrowing heavily from other parts of the university . . . .

Ackerman, The Marketplace of Ideas, 90 Yale L.J. I131, 1131 (1981). One dimension of the methodological split, then, appears to be that the new mode of analysis-Scientific Policymaking-is self-consciously interdisciplinary while the orthodox mode does not rely on the analytical tools of nonlegal disciplines to evaluate legal doctrine. This difference in techniques, of course, cuts across subject matter lines. Thus, in tort law "Guido Calabresi is different from William Prosser." Id. Calabresi is evidently cited as an example of the Scientific Policymaker who uses the tool of microeconomic theory to analyze tort doctrines, while Prosser is an example of the conventional, noninterdisciplinary legal analyst. But the division is more than just intcrdisciplinary versus noninterdisciplinary. The "Policymaking" part of the Scientific Policymaker means that such legal analysts are committed to the view that the entire legal system is premised upon, or at least can be explained as if it were premised upon, a discrete set of intcrnally consistent substantive principles. Orthodox legal analysts, while not necessarily denying the possibility that this is so, are skeptical that it is so. At least their analysis does not proceed on that assumption. It may be most accurate to characterize these Observers as indifferent to the question whether and which moral system is embedded in the legal system. Thus, their scholarship either ignores moral 
terms are purely technical. ${ }^{40}$ When the legal theory is applied to the constitutional problem of protecting property, ${ }^{41}$ the choice between these two approaches to language determines the sorts of interests that potentially constitute property.

Examining the ways that laypersons ordinarily talk about property, ${ }^{42}$ Ackerman believes, reveals the nature of the conception of property held by well-socialized members of the community who are not legally trained. ${ }^{43}$ Such investigations indicate that the ordinary layperson conceives of "things," or physical objects, as the potential subject matter of property rights. Laypersons do not distinguish between interests in property and property itself. That is, "property" is the object of the interest, the thing itself. This unitary conception of property makes it impossible for laypersons to appreciate what lawyers take for granted. For example, the legal notion of fragmented ownership, interests divided by use-rights rather than spatially, is foreign to the

debates about wealth-maximization, utilitarian, or deontological theory when analyzing various legal doctrines, or to the extent that it pays attention to questions about the moral content of legal doctrines it sees the legal system as morally eclectic.

The tendency towards Scientific Policymaking not only cuts across subject matter lines, but it also cuts across generational lines. Although it is more evident in the present generation of legal scholarship, earlier forms of Scientific Policymaking were present in past generations as well. While the modern economic analysis of law is the paradigmatic example, then, it is not without historical precedent, both of an economic and noneconomic variety. B. Ackerman, supra note 8 , at 18 n.20, 197.

40. "[T]he Scientist conceives the constituents of legal discourse to be a set of technical concepts whose meanings are set in relation to one another by clear definitions without continuing reliance upon the way similar-sounding concepts are deployed in non-legal talk.". B. Ackerman, supra note 8 , at $10-11$.

41. That there exist in modern legal culture conflicting attitudes towards the coherence of basic legal concepts is also evident in areas other than the problem of constitutional protection of property. One aspect of Richard Epstein's analysis of tort theory, for example, is an attempt to counter the view of some economists and others adopting the epistemological premises of economics that concepts like causation are indeterminate and therefore do not permit the solution of individual legal disputes. The cause of any given harm is treated reciprocally:

Logically the problem of conflicting land use is one of joint causation. It makes no more sense to say that the smoking factory causes a nuisance in a residential area than it does to say that the residents do. Take one or the other away and the problem goes away.

Donahue, The Future of the Concept of Property Predicted From 1ts Past, in Nomos XX11, Property 28, 60 n.25 (J. Pennock \& J. Chapman eds. 1980). The classic statement of this view is Coase, The Problem of Social Cost, 3 J. L. \& Econ. 1 (1960). See also Sax, Takings, supra note 6. Thus, lawyer-economists like Guido Calabresi develop substantive tort theories on the basis of alternative tools of analysis that are intended to avoid "metaphysical" or "weasel" words like "cause." G. Calabresi, The Costs of Accidents 6, n.8 (1970). Epstein's paper, Epstein, A Theory of Strict Liability, 2 J. Legal Stud. 151 (1973), attempts "to show that the concept of causation, as it applies to cases of physical injury, can be analyzed in a matter [sic] that both renders it internally coherent and relevant to the ultimate question who shall bear the loss." 1d. at 165 . His theory is that basic terms like "cause" are determined by their meaning in paradigms of ordinary language usage. Both his causal paradigm and his underlying thesis have encountered critical reactions. See Stone, From a Language Perspective, 90 Yale L.J. 1149, 1172 n.75 (1981); Borgo, Causal Paradigms in Tort Law, 8 J. Legal Stud. 419 (1979). George Fletcher recently has applied the tools of conceptual analysis to elucidate the purposes of compensation. His analysis shares some of the characteristics of Epstein's analysis of causation. Fletcher, Punishment and Compensation, 14 Creighton L. Rev. 691 (1981).

42. See infra notes 52-53 and accompanying text.

43. B. Ackerman, supra note 8 , at $97-100$. 
ordinary conception. In order to determine that a nonspatially manifested interest is their property, laypersons need the special assistance of a lawyer, and Ackerman expresses the difference between interests that are usually recognized as property by ordinary laypersons and those that laypeople are able to recognize as property only with the help of a lawyer as the difference between social and legal property. ${ }^{44}$ The existence of an alternative, scientific conception is suggested by the way that lawyers are taught to talk about property. Unlike ordinary persons, lawyers shun talk about property in thingownership terms. ${ }^{45}$ They regard statements that are taken for granted in ordinary discourse, like "John owns this book" or "this book is John's property" as confused and potentially misleading. Lawyers are taught to be skeptical of such talk and to talk about property instead in more abstract terms, using metaphors like "bundles of rights." Now, this metaphor becomes exceedingly important for Ackerman, because it serves as a window to the scientific conception of property. The bundles-of-rights idea reflects the rejection of property as spatially definable things, and the adoption of a much more abstract and dynamic mode of thinking about property. This shift permits Scientists, defined as anyone who has undergone this intellectual metamorphosis, to distinguish between things and interests in things and to see that for analytical purposes the latter notion is what is really important. ${ }^{40}$ On this Scientific view, the real question "is not to identify 'the' rights of 'the' property owner through some mysterious intuitive process, but to determine in whose bundle one or another right may best be put." 47

2. The Goals of the Legal System. Choosing the legal language determines only which interests are potentially property, and in order to decide which of these interests should be protected, it is necessary to decide which
44.
[I]n conducting his daily life, Layman will make a fundamental distinction between his social property and his legal property. As to social property, Layman will claim to be in a position to point to existing social practices which any well-socialized person should recognize as marking a thing out as Layman's thing. If, however, Layman does not believe himself justified in claiming something as his without appealing to the opinion of a legal specialist, then I shall say he has only legal, but not social, property, in the thing in question.

B. Ackerman, supra note 8 , at 117 . The legal-social property distinction is further discussed in id. at $156-67$.

45. Perhaps this statement requires some qualification. Aekerman does not claim that all lawyers talk about property in the abstract, bundles-of-right mode but only that this sort of property talk has become the expression that is dominant in Ameriean legal education in the postRealist era. Following Realist critiques of property and other concepts, American lawyers have moved to a more self-consciously scientific stance. But not all American lawyers have assimilated these modern teachings, and some have been unable to shake ordinary habits.

46. As Krier and Schwartz point out in their review, however, it is not at all clear that other scientific disciplines uniformly embrace this conception of property. Krier \& Schwartz, supra note 9. Some economists, for example, adopt a conception of property as relationships between people with respect to things, e.g., Demsetz, Toward a Theory of Property Rights, in Papers and Proceedings of the 79th Annual Meeting of the American Eeonomic Association, 57 Amer. Econ. Rev., May 1967, at 347, 347, reprinted in The Economics of Legal Relationships: Readings in the Theory of Property Rights 23, 23 (H. Manne ed. 1975), while others conceive of property as the relationship between a person and a thing, e.g., Kohr, Property and Freedom, in Property in a Humane Society 47, 49 (S. Blumerfeld ed. 1974); Krier \& Schwartz, supra note 9, at 1299 n.29. 47. B. Ackerman, supra note 8 , at 27. 
values the legal system should serve. The Observer regards the basic function of the legal system as the fulfillment of the expectations generated by the dominant social institutions. His concern is with social practices, and from examining these he hopes to ascertain the nature of the layperson's expectations. Ackerman supposes that when laypersons make property claims, they ordinarily base them on the fact that the arrested use-right is generally recognized by other members of the community in everyday dealings with them. It is the existence of some perceptible pattern of human interaction that permits laypersons to assert or withhold property claims in everyday life without constantly referring to a lawyer to advise them of their property rights. Where that observable pattern of human interaction is absent, they normally have no expectations that a property interest is theirs or someone else's because no spatial evidence of any such interest exists. Thus, the legal notion of future interests, divided temporally rather than spatially, is foreign to the ordinary conception. ${ }^{48}$

The Policymaker's basic premise differs markedly from that of the Observer. Central to the Policymaker's creed is the tenet that the legal system must be organized around a "relatively small number of abstract and general principles," 49 which together comprise a Comprehensive View. It is of no concern to him that these principles may not accord with dominant social expectations. For the Policymaker, the objective of adjudication is to act consistently with the Comprehensive View. Different Policymakers may take different positions on the nature of the best Comprehensive View, but they concur on the need for coherent and simple organizing principles.

3. Flemming v. Nestor. With this analytic framework, Ackerman believes he can explain both the coherence of the assumptions that underlie traditional takings analysis, reflected in cases like Flemming, ${ }^{50}$ and the continuity between traditional legal notions of property and Reich's thesis. That the Court first asked whether the interest asserted by Nestor was "property" suggests that the Court conceived of property in static, Ordinary terms. Ackerman further supposes that this static Ordinary conception not only provided the Court with its analytic framework, but determined the negative answer it gave to the property vel non question. Nestor's interest was in maintaining the stream of Social Security old-age benefits. This is a purely abstract interest, not manifested in any observable pattern of human activity and not even represented in any tangible form, like a piece of paper. If property is thought of in thing-ownership terms, then, it is clear that interests like Nestor's will not be treated as property. According to Ackerman, what Reich was reacting against was the Flemming Court's use of the layperson's conception of property, which led the Court first to question whether the

48. Id. at 123 .

49. Id. at II.

50. Ackerman apparently regards Flemming as symptomatic of traditional takings analysis in its very inability to link the expectations of participants who have "Iegal property" in social programs with takings law. See id. at 165. 
interest involved was property, and then rendered it unable to recognize such an unconventional form of wealth as property.

Ackerman suggests that the later entitlement cases and Reich's thcsis simply represent a variation on a conception of property familiar to most contemporary lawyers. ${ }^{51}$ Ackerman interprets Reich as adapting the legal conception to take advantage of its dynamic quality. Since property is conceived of as bundles of rights, we may treat recipients of government largesse as possessed of property interests if the central purposes and values of due process or just compensation require us to do so.

\section{The Ordinary Conception of Property}

The claim that ordinary people conceive of property rights in terms of thing-ownership stems from the premise that ordinary language is the key to understanding ordinary thinking. The philosophical heritage of this premise is the method of analyzing ordinary concepts on the basis of shared language habits, sometimes referred to as ordinary language philosophy. ${ }^{52}$ Many contemporary philosophers have focused on ordinary language in part because they believe that the shared habits of ordinary talk reflect basic insights derived through experience, ${ }^{53}$ which can then be used to illuminate fundamental questions of meaning.

I do not wish to evaluate the merits of ordinary language analysis as a philosophical technique. Rather, I question the identification of the ordinary mode of legal analysis with that philosophical tradition. The ordinary expectations and judgments with which the ordinary analyst is concerned cannot be captured simply on the basis of observing the use of the term "property" in ordinary talk because the social judgments relevant to the ordinary analyst are not simply judgments as to which specific interests the word "property" conventionally applies. Rather, the relevant considerations are the shared impressions about the circumstances under which given interests would be

51. Ackerman, Four Questions, supra note 13, at 363.

52. Ackerman has observed, "It was Wittgenstein who led me to Private Property and the Constitution." Id at 351 . It seems more clearly to have been J.L. Austin who led him to write Private Property, or to write at least that part in which he attempts to apply the tools of ordinary language analysis in order to develop the conception of property held by ordinary laypersons. For although the modern philosophical technique of conceptual analysis is certainly influenced by the later writings of Ludwig Wittgenstein, cspecially his Philosophical Investigations (G.E.M. Anscombe trans. 3d ed. 1968), ordinary language analysis was developed as a distinct philosophical method by analytical philosophers like G.E. Moore and especially J.L. Austin. Austin's paper, A Plea for Excuses, in Philosophical Papers 123 (1961), has come to be regarded as a classic expression of ordinary language analysis and has directly influenced contemporary analytical lcgal philosophers, most notably H.L.A. Hart in The Concept of Law (1961). Austin and others developed ordinary language analysis in reaction to attcmpts by some philosophers, including the early Wittgenstein (See L. Wittgenstein, Tractatus Logico-Philosophicus (D. Pears \& B. McGuinness trans. 1963)), to develop an artificial language in which concepts are precisely defined, eliminating all ambiguity in propositions. This effort can be regarded as the philosophical hcritage of Ackerman's Scientists. The philosophical conflict is described in Chappell, 1ntroduction in Ordinary Language 1 (V. Chappell ed. 1964).

53. "Ordinary language embodies . . . the inherited experience and acumen of many gencrations of men." Austin, supra note 52, at 133 . 
entitled, prima facie, to protection against given encroachments. Such expectations are not always expressed in ordinary talk in terms of "property." That term probably is most commonly used in association with the forms of wealth that are dominant in the speakers' segments of society. Other interests, less common within a group, and therefore not spoken of as property, may nevertheless be considered prima facie protectible whenever challenged. The tendency in ordinary property talk to reify interests does not, therefore, necessarily indicate that ordinary expectations depend on some form of reification.

Ackerman's reliance on the ordinary use of the word "property" leads him to an implausible model of ordinary judgments about the boundary between protectible and unprotectible interests. Both the ordinary conception of potential property and ordinary expectations about the protectibility of various interests are more subtle than Ackerman recognizes: both are determined in part by verbal representations, and not merely by superficial spatial characteristics or observable behavior.

To demonstrate that ordinary expectations need not be formed by observable conduct, I shall discuss how well-socialized laypersons would likely react to claims involving nonpossessory or conditional interests. The hypothetical situations discussed reveal that there is a tendency in ordinary thought to treat as nonproperty those interests which are subject to a power, held by the person or entity from whom the interest derives, to extinguish unilaterally all opportunity for the claimant to obtain future enjoyment of the asset.

I will then discuss the extent to which ordinary thought recognizes useinterests, as opposed to undivided interests in physical objects, as the potential subject matter of property rights. This discussion will reveal a second tendency in ordinary thought: laypersons, I suggest, recognize use-interests as potential property, but will expect protection of these interests only where the use-interest is in some way crystallized. This crystallization, I will argue, may take the form of socially observable conduct, but may also result from representations made to the interest-holder when the interest is initially conveyed.

\section{A. The Significance of Possession}

Crucial to both Ackerman's account of ordinary expectations and the distinction he draws between legal and social property is the treatment of nonpossessory interests in the scheme of ordinary expectations. One "intellectual deficiency" he finds in the ordinary person's perceptions is that the average layperson

is more willing to grant the privileged status of social property to a claimant who is capable of exercising dominion over a surfaceconnected thing at the very moment in time he is claiming the thing as his. Thus, a person who has only a future interest in a thing-no matter how ample it will be on fruition-may very easily find himself in the position of the holder of legal rather than social rights . . . . ${ }^{4}$

54. B. Ackerman, supra note 8 , at $\mathbf{1 2 2 - 2 3}$ (emphasis in original). 
Because they lack the requisite characteristic of spatial manifestation, these interests, which lawyers call "future interests," count as legal, not social, property according to Ackerman's taxonomy. As such, their protectibility, if determined by ordinary expectations, is doubtful. Through a series of hypothetical examplcs, I shall attempt to demonstrate that ordinary intuitions recognize as protectible property some of these subtler forms of wealth. I do not mean to suggest that ordinary thinking has internalized all of the technical distinctions drawn by property lawyers. Rather, I contend that the spatial criterion for property that Ackerman supposes laypersons use is implausible.

Suppose that $A$ owns a very old and rare bottle of wine that $B$ has openly coveted for some time and for which $B$ would be willing to pay a handsome price. Without more, this is an instance in which most individuals would say that though a person is subjectively interested in some asset, he does not have a property interest in it. We would recognize the difference between saying " $B$ is interested in the wine" and " $B$ has an interest in the wine." Nothing more is involved here than a unilateral desire, clearly not entitled to protectible status. $B$ 's subjective interest does not distinguish him from anyone else in the world with respect to the right to use or control the bottle of wine. $A$ may sell it to another or drink it, and in no sense would this interfere with any rights of $B$.

Suppose instead that $A$, knowing of $B$ 's great fondness for wine, one day said to him, "The wine is now yours, and I will deliver it to you next week." Would $A$ 's retention of possession of the wine lead to the perception that $B$ has no protectible interest in the wine until he actually obtains possession? It is very doubtful that ordinary expectations would so classify $B$ 's interest in this situation. If all that stands between a person and the right to possess or use an object is the passage of time, no rational basis exists for treating that person as having no protectible interest in the object.

Though Ackerman errs in believing that ordinary people will wish to accord protection only to presently possessory interests, he does seem justified in emphasizing the role of possession in ordinary expectations; the right to at least eventual possession is undoubtedly one of the characteristics ordinarily associated with "having property." 55 If, thcn, we encountered an asserted

55. Arguably, the right to possess, present or future, is not in ordinary thought a necessary condition for property rights: one could perhaps conceive of an individual who had some rights with respect to an asset - say, the bare right to control its transfer-but no hope of ever possessing it, and yet the ordiuary person would still say that the asset is that individual's property, or that the individual has a property interest in it. This is suggested perhaps by the ambivaleut treatment of powers of appointment both in the law of property and in federal tax law. Conventional property doctrine provides that the general power of appointment, defined as the ability to designate a group of persons including the holder of the power as the transferees of property, is not itself ownership but is only the authority to give ownership. For some purposes, however, such as the question of includibility of the appointive assets in the gross estate of the holder of the general power under federal transfer tax provisions, the distinetion between ownership and general powers of appointment is seen as only technical. See 1.R.C. $\S \S 2041(a)(2)$, (b)(1) (1976). For other purposes, however, such as the rights of crcditors of a holder of a general power to reach appointive property, the distinction is sometimes, though not always, recognized. Compare State Street Trust Co. v. Kissel, 302 Mass. 328, 19 N.E.2d 25 (1939) (property over which deceased held general power of appointment treated as an asset of the estate for the purpose of 
interest in an asset that was concededly subject to a condition such that the interest holder might never become entitled to possess the asset, or, if presently in possession, might lose that privilege, would we strain ordinary understanding if we were to insist that the interest in question was property? After all, more than just the passage of time separates the claimant from the object. The answer to this question depends on the nature of the conditions that may defeat possession: the existence of conditions and uncertainty does not itself render an interest nonproperty in the eyes of the ordinary person.

1. Specific Conditions on Future Possession. Suppose that $A$ tells $B$, "The rare wine is now yours and I will deliver it next week, unless, however, I run out of wine at the dinner party I am giving tomorrow night, and need the rare wine to serve to my guests." Obviously, more than the mere passage of time now separates $B$ from the wine. $A$ 's reserved right to use the wine if a certain condition occurs has considerably weakened $B$ 's prospects of future enjoyment of the wine. If we recognize $A$ 's reservation of this right as effective, can we no longer say that $B$ has a property interest in the wine? The effect of such a conclusion would be to identify as a characteristic of nonproperty any contingency that makes the right to possession uncertain. But that is unwarranted. $A$ has reserved some measure of control over the wine-the right to use it if a specified contingency arises-but he has relinquished part of his freedom to do as he wants with it. He has restricted his control over the wine in a way that assures that if the wine remains unconsumed at the end of the dinner party, $B$ will have an unconditional right to possess the wine at the end of the week. Here again, then, $B$ 's interest is more than merely subjective. It is a recognized right that is distinguished from any mere desires that others may have.

2. Open-ended Contingencies. The examples discussed so far present straightforward instances of nonpossessory interests as property. The ordinary person distinguishes these interests from mere desires ("I am interested in your wine") on the basis of an affirmative action that transfers some measure of control from the original owner to another. By that action, the owner recognizes a right in another with respect to the wine. A mere desire is a subjective interest unfounded in any positive act that recognizes a present right in the interest-holder.

The distinction between a hope or desire, on the one hand, and a property interest-albeit subject to a specific condition of defeasance-on the other, is easy to perceive and should arouse little controversy. There is another kind of condition, however, that is much more difficult to analyze. Suppose that $A$ tells $B$ that he will give him the wine next week, but reserves the right to keep it or to give it away to someone else. In one sense, $B$ 's position is stronger than that of someone who has a unilateral desire for the wine. His interest is more

satisfying debts), with Johnson v. Shriver, 121 Colo. 397, 216 P.2d 653 (1950) (power and property distinguishcd; creditor's claim denied). Recent legislation is significantly expanding creditor's rights in this area, undercutting the old dogma about the differences between general powers and ownership. See, e.g., Mich. Comp. Laws. Ann. § 556.123 (Supp. 1982). 
than a hope since it is based on a positive representation. $A$ has affirmatively identified $B$ as a potential recipient of the wine. At the same time, however, $B$ 's interest lacks what we earlier identified as the salient characteristic of a property interest. For the representation does not merely make $B$ 's right to possession subject to some measure of control by $A$, but instead leaves all control over the future use of the wine in $A$. Nothing in $A$ 's statement suggests that he has changed his position with respect to control over the wine. His statement does not result in any transfer or sharing of control with $B$, and the right he has reserved in the wine is exactly as broad as were his rights before he made the statement. $B$ 's entitlement to the future use or enjoyment of the wine is subject to $A$ 's totally unrestricted discretion. $B$ 's interest, in other words, is more than merely subject to some contingency; the contingency is completely open-ended. $B$ is a possible recipient of the wine, but so is everyone else in the world. I shall refer to interests of this sort as expectancies. ${ }^{58}$ This category of interests deserves particular attention because many of the "new property" interests, including the Social Security interest in Flemming $v$. Nestor, fall into this category. ${ }^{57}$ Classifying interests as expectancies means that they are less tenable than property interests, ${ }^{58}$ yet more crystallized than a unilateral hope or desire.

My discussion up to this point has treated any right that the recipient of a property interest acquires as a right against the world. It is possible, however, that the protectibility of an interest may vary according to the person from whom the encroachment comes, and when the source of the threat to an interest is considered, not all expectancies will be equally unprotectible.

3. Encroachments by Third Parties: Purported Present Commitment. Suppose that the original owner's representation to the claimant was, "I will give you the wine next week, unless I decide to keep it or to give it away." One important feature of this choice of words is that the owner does not appear to

56. In the context of the discussion in this section, the term "expectancy" will bc used in a broad, generic sense, to be distinguished from the narrow, technical sense in which the term is used in respect to certain common-law interests.

57. This is not to suggest that most laypersons view the interest of Social Security beneficiaries specifically as expectancies. Indeed, $I$ think it is clear that the popular view is that the payroll tax levied on covered employees represents payment into a fund in which contributors have vested interests much like the interest that one has in private insurance plans. The Flemming Court itself acknowledged that "the Social Security system may be accurately described as a form of social insurance." 363 U.S. 603, 609 (1960). This perception probably distinguishes Social Security from other social welfare programs, such as Aid to Families with Dependent Children. My point is that at an abstract level, the features of the Social Security program discussed by the majority in Flemming are the same features that cause other types of claim-interests to be considered as expectancies. The popular perception of Social Security interests as "vested" is likely due to the widespread ignorance of the very features that the Flemming Court cited.

58. The same sense seems to underlie the doctrine of illusory promises in common-law contracts. If $A$ tells $B$, "I promise to buy your car for $\$ 1,000$, unless I decide not to," the statement is normally treated as having no legal effect. See J. Murray, Murray on Contracts $\S 76$, at 148-54 (rev. ed. 1974). $A$ has left himself completely free to choose his future course of conduct. There is nothing in his statement that should cause $B$ to think that his intercst in $A$ 's car is distinguishable from anyone else's. $A$ might subsequently keep his car or sell it to another person without arousing in $B$ a sense of indignation. 
have presently committed himself. Something remains to be done in the future before the claimant's interest can be recognized as distinct from that of everyone else who may desire to own the wine.

Suppose, however, that $A$, instead of saying, "I will give you the wine next week," had stated, "I hereby give you this bottle of wine, which I will deliver next week, unless I decide to keep it or to give it away to anyone else." The same open-ended contingency is attached to $A$ 's interest here, and $A$ 's control over the wine is still secure. There is a linguistic difference, however, because $A$ has purported presently to commit himself to $B$. His statement recognizes $B$ 's interest as presently crystallized with no future action necessary. ${ }^{59}$ The question is whether $A$ 's retention of unrestricted power to terminate $B$ 's interest would be likely to cause $B$ 's interest to be treated in the same way as in the situation where $A$ 's statement indicated that $B$ 's interest was not yet crystallized. Of course, lacking empirical data, we cannot be certain about how most persons would react to these situations, but common sense suggests that the answer may depend on the source of the threat to $B$ 's interest. If the threat comes from $A$, then it is plausible to suppose that no distinction would be drawn between the two cases. Whether or not $A$ has recognized $B$ 's interest as crystallized, the condition entitles $A$ to terminate $B$ 's interest (or expectancy) with impunity, for example, by giving or selling the wine to someone else. With respect to $A$, then, $B$ has no interest that is even prima facie protectible on this ordinary view.

What if the encroachment comes from some third party? Suppose, for example, that the government were to declare that wine has a corrosive influence on public morality and ordered that all bottles of wine, including the one originally owned by $A$, be turned over to a government agency. If we concluded that $A$ was entitled to protection, by way of monetary compensation, against this governmental encroachment, would ordinary sensibilities also dictate recognition of $B$ 's interest in both situations? Here I think it is quite possible that the protectibility of $B$ 's interest would depend on the nature

59. In orthodox terms, we would characterize the statement, "I will give you the wine next week," as a promise to make a gift in the future, unenforceable in the absence of consideration or, perhaps, detrimental reliance by the promisee. By contrast, the statement, "I hereby give you the wine next week," is not promissory, but a present gift of a future interest in the bottle of wine. Courts frequently state that an inter vivos gift must be absolute, unconditional, and irrevocable in order to be valid. See, e.g., Wright v. Bragg, I06 F. 25 (7th Cir.), cert. denied, I86 U.S. 486 (I901). This rule is not without exceptions, however. Courts have upheld gifts where the subject matter is not to be delivered until some future time, such as the donor's death, where the donee's right to receive the asset cannot be revoked by the donor. See, e.g., Innes v. Potter, $130 \mathrm{Minn}$. 320 , I53 N.W. 604 (19I5). Gifts of vested future interests in personalty have been upheld even where the donor reserved the right to use and enjoy the asset during his lifetime. E.g., Jackson v. Lamar, 67 Wash. 385, 121 P. 857 (1912). Courts have also upheld as valid gifts present transfers of possession of some asset, subject to a condition subsequent, although other courts have rejected these. Compare Blanchard v. Sheldon, $43 \mathrm{Vt}$. 512 (187I) (\$300 vested in donee subject to defeasance until donor's death), with Devine v. Stepanek, 176 Ill. App. 61 (I912) (donor reservation of right to repossess invalidates gift), and Jones v. Luing, 152 Iowa 276, 132 N.W. 371 (I911) (same). See generally R. Brown, The Law of Personal Property §§ 7.12-.13, at 114-27 (W. Raushenbush 3d ed. 1975). 
of the representation made by $A$. Where $A$ has said, " 1 hereby give this wine to you ...." $B$ 's interests would be regarded as prima facie protectible against third-party encroachment, even though $A$ has retained unlimited power to terminate that interest. But where $A$ 's statement is, "I will give this wine to you next week . . .," $B$ 's interest would be deemed unprotectible, not because of $A$ 's retained power but because his statement did not recognize $B$ 's interest as presently crystallized.

There may be some temptation to regard this distinction as artificial, a matter only of form, and lacking substantive coherence. If in both situations, $A$ has the unlimited power to eliminate any possibility that $B$ will enjoy the wine, the status of $B$ 's interest substantively would be the same. The condition that $A$ not exercise his power would override any distinction based on the form of $A$ 's statement, "I will give" or "I hereby give."

It is always easy to assert that a distinction is formal only and therefore should be ignored. But a distinction is purely formal only if it describes the same event in different ways. A distinction made between two different events is not simply a matter of form. The statement, "I hereby give you this wine, to be delivered next week, unless I choose to keep it or otherwise dispose of it," describes an event that is different from that described in the statement, "I will give you this wine next week, unless I choose to keep it or otherwise dispose of it." The first statement purports presently to transfer an abridged ownership interest. Because of the language used, we recognize the interest as having already come into being. The interest may be extinguished by $A$ 's exercise of his power, but that contingency only indicates that, with respect to $A$ 's actions, $B$ has only an expectancy, a nonprotectible interest. $A$ 's retained power does not necessarily imply that with respect to threats by third parties $B$ has only an expectancy. His interest would be unprotectible against thirdparty encroachments only if there existed no action that purported prcsently to create in him a right to enjoyment of the wine, whether that use-interest is present or future, abridged or unabridged. That is precisely the effect of the second statement. The significance of the words there is that the existence of $B$ 's use-interest in the wine is dependent on some future action by $A$. If $A$ subsequently sells or gives away the wine, the effect is not to take away from $B$ a recognized interest, but to preclude future recognition of a use-right in $B$.

We have arrived, then, at the point where the distinguishing characteristics of expectancy interests can be stated. Interests may be expectancies, unprotectible according to ordinary expectations, either because they depend on future recognition by another (such as a grant by an owner) or because they are subject to another's unlimited power to extinguish the present or future enjoyment of the asset in question and therefore are unprotectible against that person's encroachments. ${ }^{60}$

60. I recognize that there may be instances where such a power is expressly retained yet ordinary perceptions would judge the formally subordinate interest to be prolectible because failure to exercise the power over an extended period of time has led to its being ignored. Thus the market value for such an interest would not be discounted by the existence of a formally retained power but would be the same as if no such power had been retained. 
In more general terms, these features indicate that ordinary thought requires that an interest, to be protectible as property, must in some manner be crystallized. Ackerman's account reflects the same claim, for his requirement that the interest be manifested in some socially observable conduct is one means of crystallizing an interest, through reification. But interests may be crystallized in other ways. They may be crystallized and become ordinarily recognizable as property on the basis of representations alone. Statements granting to another person a present right to use or enjoyment-interests that lawyers variously label easements, profits, or leases-are comprehensible in ordinary life as creating protectible property whether or not the right is presently exercised and spatially observable. ${ }^{61}$ As a result, the distinction between existing and future use is not in itself determinative of ordinary expectations.

\section{B. The Problem of Use-Rights}

Ackerman maintains that ordinary people have difficulty conceiving of what lawyers call use-interests. That is, the only potential property interest that they understand is the complete and unified set of rights to control a physical object. Moreover, he believes that laypersons will attribute this full measure of ownership to the individual who has the largest number of userights manifested by socially observable conduct. Both aspects of his account of the ordinary person's view are, I believe, mistaken.

1. Use-Rights as Potential Property. Suppose that $A$ proudly purchases a new gas-powered leaf-blower, and no longer needs his old rake. He transfers the rake to his neighbor, $B$, saying, "This rake is now yours, but if my leafblower ever breaks down, you must let me use my old rake." Would the layperson be unable to comprehend the idea that, after the transfer, both $A$ and $B$ could be said to have an interest in the rake? Suppose that, at some point, $A$ does need to use the rake, and requests that $B$ temporarily surrender possession of it. $B$ refuses, however, saying that it is not possible for both $A$ and he to "own" the rake, and that $A$, in transferring the major part of the bundle-of-rights, had relinquished any interest in the rake. I think that most laypersons would regard $B$ as a rather dishonorable character, and would feel that $A$ had a perfectly good right to enforce the condition of his gift. This conviction, moreover, would not stem from a belief that $A$ rather than $B$ was the "real owner" of the rake. Suppose $A$, instead of asking $B$ for the rake solely because the power blower was broken, told $B$, "I don't like you any more, and I want to take the rake back and give it to $C$." Most people would feel that $A$ had foreclosed by the terms of the transfer any future right of control over the rake except to the extent that his power blower proved unreliable. Thus, ordinary expectations about the respective rights of $A$ and $B$ indicate that both are viewed as having a set of use-rights in the rake.

61. It is entirely possible, even likely, that ordinary individuals will have more concern with proof that such representations were in fact made in the context of interest in future use or enjoyment than with respect to existing uses. But these evidentiary concerns do not themselves justify the claim that laypersons are unable or unwilling to regard such interests as property. 
2. The Protectibility of Use-Interests. Under what circumstances will laypersons expect a use-interest to be protected? Ackerman suggests that the most important factor in this determination is whether or not the use-interest is presently exercised.

It seems implausible, though, that the rights of either $A$ or $B$ in the previous hypothetical would depend on exercise of the use-interests allocated to them by the initial grant. The terms of the grant alone seem sufficient to establish their rights.

It is also important to note that the fact that a use-interest is presently exercised is not in itself a sufficient ground for concluding that the interest in question is property. Suppose that $A$, instead of telling $B$ that the rake is now $B$ 's, says instead, "I no longer have much use for my rake, and you may borrow it, but you must return it to me if I so request." If $B$ does borrow the rake, he obtains present possession but clearly no ownership interest in the rake. In contrast to the situation where $A$ specified a particular circumstance in which he would reclaim the rake, the ordinary person would feel that $A$ now has a right to take back his rake for any reason at all, even a purely capricious one ("I have decided I don't like you any more"). Thus, presentlyexercised use-rights can be made vulnerable to revocation by the grantor in just the same ways as future interests in things can be.

Present exercise also seems unnecessary to establish rights against third parties. Suppose that $A$ owns a large piece of land, most of which he has never used in any way. One of the distant, unused corners provides a convenient access for $B, A$ 's neighbor, to his own property. If $B$ decides one day to use the route, laypersons would be unlikely to feel that $A$ had waived his right to exclude $B$ by his nonuse of that piece of property.

But Ackerman's contention that present exercise is needed to establish a protectible use-interest does seem plausible in the situation where the encroachment made on the interest is indirect. Suppose that one of the many unused portions of $A$ 's land is a lakefront suitable for recreational activities. $A$ has a somewhat eccentric neighbor, $C$, who owns the property adjoining the beach. He has been using his property to conduct various experiments in alchemy. These give off a noxious odor, which makes $A$ 's beach unusable for recreation, but which spreads no further than the beach on $A$ 's property. If $A$ were to insist that $C$ cease interfering with his beach, laypersons would probably feel that $A$, because of his nonuse of the beach, had no right to prevent $C$ from indulging his harmless peculiarities simply to vindicate some abstract right to the use and enjoyment of the beach. If, however, $A$ had been using the beach all along, before $C$ began conducting his experiments, most people would feel that $A$ had considerably less obligation to tolerate $C^{\prime}$ s idiosyncrasies.

\section{Ordinary and Legal Culture}

Ackerman treats ordinary culture as indifferent to the terms by which a grantor conveys an interest to a grantee. It is counterintuitive to suppose that legal and popular thought would be so fundamentally different. A minimal 
degree of basic compatibility between ordinary and legal thought seems a necessary condition for the stable existence of any legal system. And it does not seem too much to expect of well-socialized nonlawyers that they would have some appreciation of the significance of a grantee's conferring upon another individual or group a right that is by convention associated with the popular as well as the legal conception of ownership. Moreover, we should not overlook the role that legal doctrines, especially those deeply embedded in our legal culture, have in shaping ordinary expectations.

This hypothesis of greater compatibility between legal and popular culture suggests that no distortion or manipulation of ordinary property thought is required to conceive of presently unexercised use-interests or nonpossessory interests in physieal objects as property. Again, this is not to suggest that legal and ordinary thought are identical, either in locating the boundary between property and nonproperty or in the basis upon which the boundary is defined. But if this analysis even partly succeeds in capturing ordinary expectations concerning the circumstances in which interests are or are not prima facie protectible, it provides ample ground for rejecting Professor Ackerman's account of those expectations as directed by the spatial characteristics of claim-interests. It indicates that ordinary expectations depend instead on abstract characteristics that cut across spatial distinctions. As a consequence, ordinary thought is a more adequate basis upon which to evaluate the status of a much broader range of interests than Ackerman allows, including claiminterests popularly labeled as the "new property."

The suggestion of a closer relationship between ordinary and legal thought about property is developed in the next part. Specifically, I shall argue that the tendency in ordinary thought to treat as nonproperty subordinated interests is also reflected in legal doctrines distinguishing between property and nonproperty. The tendency is widely, but not invariably, evident in the common law of property. As evidence of the tendency, I shall discuss several examples of common-law distinctions between property and lesser types of interests. Though there have been exceptions to it, the tendency has been persistent throughout the common law of property.

After establishing this relationship between ordinary thought and common-law distinctions, I trace the same tendency in the context of modern constitutional property doctrines, including both Flemming $v$. Nestor, where substantive protection is at issue, and more recent procedural due process cases. The thesis of this section is that these constitutional decisions, in which protection for "new property" interests was denied, represent an extension of the conceptual structure of established common-law doctrines, which in turn were fundamentally compatible with ordinary property thought. At a purely conceptual level, then, Flemming can be said to be quite consistent with the ordinary conception of property. Far from indicating the analytical inadequacy of the ordinary conception, then, Flemming is evidence of the continued capacity of this conception to clearly and positively distinguish between property and nonproperty. There remains, however, the question of how to explain the recent shift away from the established, ordinary/common-law 
conception of property toward a scientific conception, illustrated by the theory of the "new property." Part V addresses that question.

\section{Property and Nonproperty in the Common LAW}

The common law of property is notable for its elaborate classification and categorization of interests. ${ }^{62}$ At several points within its scheme, common-law doctrines relegate particular interests to categories of "nonproperty." That is, they distinguish between these interests and other types of interests that are characterized as "property." These distinctions carry substantive implications: the nonproperty interests get relatively less protection than do the property interests and their use may be restricted in ways that property interests are not.

The distinctions made by the common-law are, I believe, consistent with the description of the structure of ordinary thought set out in Part II. This congruence between the ordinary and the legal categories of property and nonproperty provides ample grounds for rejecting Ackerman's contention that the ordinary person is conceptually unequipped to understand why the common law protects some nonpossessory interests or use-interests and not others.

\section{A. The Problem of Possession}

That the common law regards certain non-presently-possessory interests as protectible property hardly needs to be pointed out. Perhaps the most obvious class of such interests are those that have no condition attached to future possession. Indefeasibly vested remainders and springing and shifting executory interests without a contingency ${ }^{63}$ are examples of interests that count as common-law property. The common law understands the holder of the interest to be in the same position as the individual in my earlier hypothetical who was told, "The wine is now yours, and 1 will deliver it next week"; only the passage of time separates the interest holder from possession.

That a specified condition may defeat the interest-holder's future possession does not preclude classification of an interest as property under the common law. Contingent remainders, vested remainders subject to divestment, and most executory interests are all future interests subject to a condition not certain to occur. ${ }^{64}$ These interests are classified as property, and the common law grants them protection from encroachments by either the grantor or by third parties. These interests are like that held by the individual who was told, "The rare wine is now yours, and it will be delivered next week

62. Charles Donahue describes the process of categorization in the development of property rules as associated with a fundamental tendency in Western legal systems to agglomerate in a single person, commonly the prcsent possessor of the object in question, all rights, privileges, and powers concerning the object. Donahue, supra note 41 .

63. 1 American Law of Property $\$ 4.1$ (A. Casner ed. 1952).

64. Id. § 4.102-.104. 
unless I run out of wine at my dinner party tomorrow, and need the rare wine to serve to my guests"; only the condition specified in the grant that created the interest will be allowed to defeat possession.

How does the common law treat those interests that, in discussing ordinary thought, I referred to as "expectancies"? In the common law, that term is most commonly used in connection with the succession interests of presumptive heirs and legatees and potential appointees of general powers of appointment. ${ }^{65}$ But courts have applied the term to other interests as well, including the interest of a beneficiary of a revocable life insurance policy, ${ }^{66}$ inchoate dower and curtesy interests, ${ }^{67}$ and a wife's interest in community property during marriage. ${ }^{68}$ At first glance these interests appear to have little or nothing in common. It is tempting to conclude that the term "expectancy" is purely conclusory, a label that courts attach to whatever interests they decide not to protect for various, unrelated reasons. However, a closer inspection of the interests that are characterized with some regularity as expectancies reveals that they do share a common characteristic. At the time when the expectancy characterization was applied to each interest, the interest was vulnerable to a legally recognized power of termination held by another person. The existence of this power meant in each case that the interestholder's entitlement to future possession or enjoyment of the object of the interest could be extinguished at the unrestricted discretion of another person.

Probably the most frequent use of the term "expectancy" in the common law is in connection with the succession interest of the presumptive heirs and legatees of a living ancestor or testator, as the case may be. An ancient maxim provides that the living have no heirs: Nemo est haeres viventis. The persons who would be the heirs of $A$, a living person, if $A$ were to die immediately, are not the heirs of $A$ but the heirs apparent. Orthodox doctrine declares that heirs apparent do not have a property interest, only an "expectancy." The

65. See 1 L. Simes \& A. Smith, The Law of Future Interests $\S 391$, at 410-11 (2d ed. 1956). The English courts sometimes use the term "spes successionis" to refer to these interests.

66. See, e.g., Sussman v. New York Life Ins. Co., 32 F. Supp. 88 (E.D. Pa. 1940); Page v. Washington Mut. Life Ass'n, 20 Cal. 2d 234, 242, 125 P.2d 20, 24 (1942); McKenty v. Caldwell, 287 Ky. 750, 753, 155 S.W.2d 193, 194 (1941).

67. See, e.g., Randall v. Kreiger, 90 U.S. (23 Wall.) 137, 148 (1874); Rogers v. Leahy, 296 Ky. 44, 48, 176 S.W.2d 93, 95 (1943); Opinion of the Justices, 337 Mass. 786, 789, 151 N.E.2d 475,477 (1958).

68. See, e.g., Spreckels v. Spreckels, 116 Cal. 339, 344-45, 48 P. 228, 229 (1897); Van Maren v. Johnson, 15 Cal. 308,311 (1860).

69. Historically, the term "expectancy" seems to have come into use first in connection with the heir apparent's succession interest. It seems likely that originally the heir's interest in his ancestor's estate came to be regarded as not property less because of conceptual difficulties than because of functional considerations. In England during the late twelfth century, the heir began to lose control of his ancestor's alienation, with all rights, privileges, and powers being concentrated in the ancestor. Compare R. Glanville, Glanvil 71 (G. Hall trans. 1965) ("If he has both inherited and acquired land ... he can give in perpetuity any part or all of his acquired land to whom he pleases."), with Bracton's Note Book, pl. 1054. By the time Coke and Blackstone were writing, the distinction between title to land by descent and by purchase had fully developed, implying that the heir had no legally recognizable property interest during the ancestor's lifetime. See $2 \mathrm{~W}$. Blackstone, Commentaries *201. Thus, the "expectancy" characterization of the heir apparent's 
same label is given to the interests of persons who are named as beneficiaries in the will of a living person. ${ }^{70}$

The succession interests of presumptive heirs and legatees are more than unilateral hopes or desires. Some positive basis exists for their interest. The basis for the legatee's interest, of course, is the representation in some testament identifying the persons whom the testator wishes to benefit upon his death. The expectant heir's interest derives from intestacy statutes which prescribe the course of succession in the event that an individual dies without effectively disposing of all his wealth, inter vivos or by will. Nonetheless, these interests, though more tenable than unilateral hopes, are not conventionally regarded as property.

The individual who has not yet made a will may yet write one; the living testator may change the terms of the will that would be in force were he to die today. If either of these circumstances were to occur, the presumptive heir or legatee would not be permitted to challenge a change that reduced or eliminated his interest in the ancestor's property. The presumptive heir or legatee is thus in the same position as the individual who was told, "You will receive my wine next week unless I decide to keep it or to give it to someone else."

Classification of these interests as expectancies rather than property has other substantive implications. For example, heirs apparent and potential

interest cannot be seen as the product of any overall effort to systematize interests into clear, discrete categories. Rather it was the result of a social and legal change regarding family ties to property and the configuration of power over property within the family, from a situation where power was shared by the ancestor with other family members to one where control over property is concentrated in one person, the ancestor. This change is an illustration of what Donahue calls the agglomerative tendency in the Western concept of property. See Donahue, supra note 41 . It was only later that the notion of an expectancy was conceptualized into a discrete legal category as systematic legal thinking moved the meaning of the term to a higher level of abstraction. Courts that characterized other interests as expectancies frequently pointed to the heir apparent's interest and emphasized the heir's vulnerability to the ancestor's unrestricted control over the assets in his estate as the defining characteristic of the heir's interest as an expectancy. The systematization of the term into a discrete legal category was promoted by treatise writers of the nineteenth century. One writer provides the following definition of an expectancy as a separate class of interests:

An expectancy or chance is a mere hope, unfounded in any limitation, provision, trust or legal act whatever; such as the hope which an heir apparent has of succeeding to the ancestor's estate. This is sometimes said to be a bare or mere possibility, and, at other times, less than a possibility. But it is less than a possibility in the specific sense of the term possibility. For, it is no right at all, in contemplation of law, even by possibility; because, in the case of a mere expectancy, nothing has been done to create an obligation in any event; and where there is no obligation, there can be no right because right and obligation are correlative terms.

J. Smith, An Original View of Executory Interest in Real and Personal Property $\S 71$, at 23 (1845). This work was intended, as its subtitle indicates, to form "a body of notes" on Charles Fearne's great treatise, originally published in 1772, An Essay on the Learning on Contingent Remainders and Executory Devises. None of the many editions to Fearne's treatise, however, treats expectancies as a distinct category of interest. The formalization of expectancies seems to be the product of nineteenth-century tendencies rather than of earlier trcatise writers likc Fearne.

70. See Restatement of Property $\S 315$ (1940). In a few states it is provided by statute that the expectancy of an expectant heir or legatee is not to be deemed an interest of any kind. E.g., Cal. Civ. Code $\S 700$ (West 1982); Mont. Code Ann. $\S 70-1-319$ (1981); N.D. Cent. Code $\S 47-02-20$ (1978). 
legatees may not effectively transfer their interests by gratuitous quitclaim assignment. ${ }^{71}$ Attempts to assign or sell are not recognized at law because, the usual expression goes, the putative grantor has nothing to assign or transfer. ${ }^{72}$ Nevertheless, a contract to convey the inherited interest in the future is specifically enforceable in equity, so long as fair and substantial consideration is given in exchange for the expectant heir or legatee's promise to convey his interest. ${ }^{73}$ And transferors by warranty deed are estopped later to deny the validity of the transferee's interest. ${ }^{74}$ These apparent cracks in the general nonrecognition of expectancy interests do not, however, necessarily represent concessions to the property status of these interests. They can be viewed as extensions of equity rules that have general application. The rule recognizing equitable assignability of expectancies for adequate consideration is sometimes explained as only a consequence of specific enforcement of a contract to convey, here when the ancestor dies. ${ }^{75}$ Alternatively, where the expectancy is in personalty, rather than in land, it has been explained as an extension of the doctrine of Holroyd $v$. Marshall. ${ }^{76}$ This doctrine provides that

if a vendor or mortgagor agrees to sell or mortgage property, real or personal, of which he is not possessed at the time, and he receives the consideration for the contract, and afterwards becomes possessed of property answering the description in the contract, there is no doubt that a Court of Equity would compel him to perform the contract, and that the contract would, in equity, transfer the beneficial interest to the mortgagee or purchaser immediately on the property being acquired. ${ }^{77}$

This principle is broad enough to apply equally to situations where the assignor has neither title nor an expectancy, ${ }^{78}$ indicating that the equitable

71. See L. Simes \& A. Smith, The Law of Future Interests $\S 395$ (2d ed. 1956).

72. See, e.g., Engle v. Walters, 282 Ky. 732, 734, 140 S.W.2d 402, 403 (1940); Meek v. Kettlewell, 41 Eng. Rep. 662 (1843).

n

73. E.g., Bridge v. Kedon, 163 Cal. 493, 498-99, 126 P. 149, 152 (1912); Casady v. Scott, 40 Idaho I37, 156, 237 P. 415 (1924); In re Lind, [I915] 2 Ch. 345, 360. See Restatement of Property $\S 316$ comments c \& d (1940).

Courts have been somewhat reluctant to enforce such contracts and have tended to review the "fairness" of the exchange rather closely. Professor Dawson explains the Chancery decisions during the formative period as an effort "to prevent dispersal of family estates through improvident sales by their prospective owners. The motive was clear-to preserve for a dominant class the economic resources on which its prestige and power depended." Dawson, Economic Duress-An Essay in Perspective, 45 Mich. L. Rev. 253, 268 (1947). See also Evans, Certain Evasive and Protective Devices Affecting Succession to Decedents' Estates, 32 Mich. L. Rev. 478, 488-91 (1934).

74. See Somes v. Skinner, 20 Mass. (3 Pick.) 51, 60 (1825); Blackwell v. Harrelson, 99 S.C. $264,270,84$ S.E. 233, 235 (1914). Equity courts did not enforce these agreements as readily as law courts enforced, at least in theory, normal transactions. They did not predicate enforceability on the presence of consideration sufficient at law to support a contract. Rather, enforceability openly depended upon the existence of substantive value given in exchange for the expectancy. In effect, then, they reserved the right to do what the classical bargain theory of contracts forbade-to review the substantive fairness of the exchange.

75. See In re Barnett, 124 F.2d 1005, 1007-08 (2d Cir. 1942); Hooker v. Hooker, 130 Conn. 41, 32 A.2d 68 (1943); Donough v. Garland, 269 11l. 565, 567, 109 N.E. 1015, 1016 (1915).

76. 11 Eng. Rep. 999 (1862). See In re Lind, [1915] 2 Ch. 345.

77. Holroyd, 11 Eng. Rep. at 1007.

78. See 1 S. Williston, The Law Governing Sales of Goods $\$ \S 138-42$ (2d ed. 1924). 
assignability of expectancies does not have to be taken as transforming them into property.

Similarly, although the holder of an expectancy is protected against misrepresentations designed to induce the ancestor or testator to disinherit the expectant heir or legatee, ${ }^{79}$ courts have not conceded that such protection implies recognition of the expectant heir or legatee's interest as property, properly so called. Responding to the argument that the disappointed heir or devisee is not entitled to any relief where the ancestor or testator has been fraudulently induced to disinherit him, ${ }^{80}$ courts have stated that equitable relief is available to prevent unjust enrichment not only in cases of invasion of common-law rights of property but also in favor of "disappointed hopes and unrealized expectations." "81 Thus, the granting of relief against wrongful interference with expectancies is seen as an application of the general rules protecting interests in advantageous relations, including prospective advantages. ${ }^{82}$

The treatment of these succession interests as nonproperty certainly does not rest on a supposition that they are too insubstantial to be worth protecting. Occasionally, one finds expressions of the view expressed in the maxim de minimis non curat lex, but this does not seem to be the basis for the status of these interests as expectancics. Indeed, it is widely recognized that the interests of expectant heirs and legatees may have as much or more economic significance as some interests that are routinely classified and protected as property. The Restatement of Property, for example, while endorsing the orthodox classification, acknowledges that the expectancy interests of heirs apparent and presumptive lcgatees may be economically capitalizable and may have exchange value:

Viewed realistically, many future intcrests and the interest of an expectant distributee consist of a "chance" to become the owner of property. The "chance" of an expectant distributee is often more likely to result in economic advantage to him than the "chance" represented by an interest conceded by all to be a valid remainder or executory interest. ${ }^{83}$

79. For a recent case discussing protection of expectancies against tortious interference, see Nemeth v. Banhalmi, 99 Ill. App. 3d 493, 425 N.E.2d 1187 (1981). See generally Restatement (Second) of Torts § 774B (1977).

80. See Hutchins v. Hutchins, 7 Hill 104, 109 (N.Y. 1845).

81. Latham v. Father Divine, 299 N.Y. 22, 85 N.E.2d 168, 170 (1949). In Latham, relief, by way of a constructive trust, was granted against wrongful interference with the making of a will in favor of the plaintiff. Some cases have permitted the disappointed devisee or heir to recover damages in an action at law for tort to his expectancy, rather than constructive trust relief. E.g., Bohannon v. Wachovia Bank \& Trust Co., 210 N.C. 679, 188 S.E. 390 (1936). The difference may be important if the defendant has not been personally enriched as a result of his actions. Under such circumstances, there is no basis for constructive trust relief. See Evans, Torts to Expectancies in Decedents' Estates, 93 U. Pa. L. Rev. 187 (1944).

82. The expansion of legal protection to advantageous relations is usually seen as beginning with Lumley v. Gye, 118 Eng. Rep. 749 (Q.B. 1853). For an interesting interpretation of this case and its subsequent development, see Note, Tortious Interference with Contractual Relations in the Nineteenth Century: The Transformation of Property, Contract and Tort, 93 Harv. L. Rev. 1510 (1980).

83. Restatement of Property $\S 315$ comment a (1940). 
There is, of course, no inherent obstacle to classifying these interests as property and treating them as fully transferable and protectible against thirdparty interference in the same way as other nonpossessory interests are. That they are not so classified or treated can be related to the broader tendency in Anglo-American property law to concentrate control over assets in one person or entity, preferably the one who is presently entitled to possession. ${ }^{84}$ To the extent that the expectant heir, legatee or trust beneficiary is free to anticipate his inheritance, the ancestor loses control over the disposition of his estate. Such a loss of control implies notions of sharing and collective control and enjoyment within the family unit that were rejected by English courts in the early thirteenth century as the rights of kindred to obstruct or cancel transfers of ancestral land faded away. ${ }^{85}$ Without denying the significance of the social and intellectual forces that influenced the development of the orthodox doctrine that classifies these interests as expectancies, I wish to bring to the surface an aspect of these interests that relates that classification to the conventional legal perception of other particular interests as also not rising to the level of property.

We are so accustomed to explaining legal phenomena in terms of policies that we tend to forget how much our legal doctrines owe to the tendency to abstract and conceptualize legal developments. ${ }^{86}$ The notion that an expectancy is a nonproperty interest illustrates this tendency. An expectancy has become associated with a cluster of interests that share an abstract characteristic in common with the succession interests of expectant heirs and legatees. The characteristic that distinguishes these interests is the fact that they occupy a dependent relationship with another interest in the same asset. Where $A$ is empowered to dominate $B$ and $B$ is subordinate to $A$ in the sense that $A$ holds some sort of Hohfeldian power that enables him at will to extinguish $B$ 's

84. See supra note 60 .

85. See J. Dawson, Gifts and Promises 29-36 (1980); 2 F. Pollock \& F. Maitland, The History of English Law 308-13 (2d ed. 1923).

86. Joseph Vining's discussion of the concept of property in the administrative law context is rich with insights and sensitivity to the power of conceptual thinking. I have profited from his analysis, of which the following passage is suggestive:

Unsympathetic smiles may be evoked by talk today of a concept of property or indeed a concept of anything. So accustomed are we to concentrating on reasons of policy and on the conclusory nature of legal categories that we tend to forget how channeled we are by nothing more than a conceptual structure. We may look to consequences before we come to our conclusion about a matter of law and affix the linguistic label, but we look only for relevant consequences, ask only a limited number of questions. Time and the complexity of things make it impossible to do otherwise. There are limits to the movement of our minds, shared boundaries for which there is no better name in legal analysis than "concepts"- conclusions that we could question but choose not to, premises for ordered thought and communication. Certainly analysis of property interests has had limits beyond which we have chosen not to stray. We have gone beyond the point of assuming that property consists only of those expectations that could have been experienced in a preindustrial age. But we have not questioned that a property interest must be a claim to something that all others do not share or that it must be traceable to some sovereign grant to a named body.

J. Vining, Legal Identity 24 (1978). 
present or future possession or use of the asset, $B$ 's interest is an expectancy, an interest not regarded as of the same order as fully protectible "property" interests. Distilling this characteristic from the expectant heir's succession interest, which was already established as nonproperty, courts utilized it as a criterion for determining the conceptual status of other interests whose legal protection was sought. It evolved into a distinct legal idea that is evident in several corners of private law. I shall refer to the tendency to categorize interests as "expectancies" or some other form of unprotectible "nonproperty" interest on the basis of this conceptual characteristic as the principle of subordinated interests.

The notion of subordinated interests as nonproperty also explains the conceptual problems courts experienced when first confronted with other transactions in which a person other than the designated transferee or beneficiary held an unlimited power to terminate the beneficiary's entitlement to possess or enjoy the assets in question. For example, the judicial reaction to revocable inter vivos trusts and to discretionary trusts illustrates the tendency to regard the existence of unlimited control over an asset in one person as implying that no other person holds a property interest in that asset. Under the typical revocable inter vivos trust, one person (the settlor) transfers assets to another as trustee pursuant to a writing in which the settlor retains the power to revoke, alter, or amend the trust and the right to trust income during his lifetime. On the settlor's death the assets are distributed to or held in further trust for other beneficiaries. Although all American jurisdictions now recognize the validity of a trust in which the settlor reserves the power to revoke during life, several early cases held these trusts invalid if they were not executed in compliance with requisite testamentary formalities. ${ }^{87}$ The conventional account of these cases is that they resulted eithcr from a desire to preserve the probate process as the sole or primary means of transferring wealth at death or from a strong view of the policies expressed by wills statutes. Although these factors were evidently present in early reactions against these trusts, ${ }^{88}$ the struggle over revocable living trusts also resulted from conceptual difficulties that courts had with the notion that the settlor had transferred a property interest to a beneficiary where he reserved complete control over the trust assets until his death. The beneficiary was viewed as having no property interest in the trust property until the settlor's death, when

87. The influential decision holding invalid those testamentary trusts created during the settlor's lifetime in which the settlor retains the power to revoke the trust is McEvoy v. Boston Five Cents Savings Bank, 201 Mass. 50, 87 N.E. 465 (1909). This decision was followed by several other courts during the early twentieth century, at about the same time as the revocable feature of life insurance policies caused courts to characterize the designated benefieiary's interest as merely an expectancy until the insured's death. E.g., Union Trust Co. v. Hawkins, 121 Ohio St. 159, 167 N.E. 389 (1929) (reserved right to stock income, reserved power to revoke and power to control investments); Darling v. Mattoon State Bank, 189 Wis. 117, 207 N.W. 254 (1926) (certificate of deposit, to be under settlor's control); Warsco v. Oshkosh Sav. \& Trust Co., 183 Wis. 156, 196 N.W. 829 (1924) (certificates of deposit, power to demand repayment). It was later overruled in National Shawmut Bank v. Joy, 315 Mass. 457, 53 N.E.2d 113 (1944).

88. See, e.g., Union Trust Co. v. Hawkins, 121 Ohio St. 159, 167 N.E. 389 (1929). 
the settlor no longer could exercise his control. The inter vivos transfer to the beneficiary was considered to be formal only; substantively, there could be no transfer of a property interest until the termination of control resulting from death.

The same reasoning can be found in cases dealing with true discretionary trusts. These are trusts in which the trustee is given complete discretion to refuse to pay or apply any of the trust property to or for the benefit of the trust beneficiary and where the settlor either retains an equitable reversionary interest in any funds that the trustee chooses not to distribute, or designates a recipient for such funds. Even in jurisdictions that do not recognize spendthrift trusts, creditors and transferees of the beneficiary of a discretionary trust cannot compel the trustee to pay over any part of the trust property. In some cases this result has been explained on the ground that because of the trustee's absolute discretion, the beneficiary had no property interest in the trust assets, and therefore he had nothing that could be transferred or attached. ${ }^{89}$ The principle here is the same as in the revocable trust cases: the concentration of control over assets in a person who has the ability to defeat the possessory interest of another person means that the subordinated interest is conceptually not property.

\section{B. Third-Party Encroachments on Expectancies}

The common law exhibited a tendency ${ }^{90}$ to treat the interest-holders discussed so far in this Section-presumptive heirs and legatees, and benefi-

89. See, e.g., Duncan v. Elkins, 94 N.H. 13, 45 A.2d 297 (1946). Restatement (Second) of Trusts $\S 155(2)$ (1957) does not necessarily reject the view that until the trustee exercises its discretion in favor of the beneficiary of a true discretionary trust, the beneficiary has no property interest. That section provides:

Unless a valid restraint on alienation has been imposed . . . if the trustee pays to or applies for the beneficiary any part of the income or principal with knowledge of the transfer [by the beneficiary of his interest in a discretionary trust] or after he has been served with process in a proceeding by a creditor to reach it, he is liable to such transferee or creditor.

The only authority cited for this rule was Hamilton v. Drogo, 241 N.Y. 401, 150 N.E. 496 (1926). Restatement of Trusts 120 (Tent. Draft No. 2, 1931). According to that case, the beneficiary would realize an attachable property interest even before he had received the income or principal allotted to him by the trustee but not until the trustee had exercised its discretion in favor of the beneficiary. This principle had been developed in an earlier English case involving an assignment by a beneficiary of a discretionary trust. In In re Neil, 62 L.T.R. (n.s.) 649, 651 (1890), the court, per Kekewich, J. rejecting the trustee's argument that the income distributed to the beneficiary did not belong to him until actually paid and hence that the beneficiary had nothing to assign, stated, "I think that it must be assumed that money paid by the trustees to him or to any person in his behalf was his in their irrevocable determination immediately before the payment. At that period of time they [trustees] had notice or were affected with notice of the assignment." See also Canfield v. Security-First Nat'l Bank, 13 Cal. 2d 1, 87 P.2d 830 (1939).

90. That it is now settled that the beneficiaries of revocable or discretionary trusts have, for most purposes, protectible property interests should not lead us to overlook the difficulties that courts earlier experienced in dealing with those interests. Nor have these conceptual difficulties totally disappeared today; it is of some significance, I think, that many of my students have puzzled over the classification of such vulnerable interests as property. 
ciaries of revocable and discretionary trusts-as having only expectancies, not protected as property. In discussing the structure of ordinary thought, 1 maintained that where a grantor purported to make a present transfer of a right, a layperson might expect that the interest created would be protected against third party encroachments even if an open-ended contingency were attached to the grant.

The status of beneficiaries under life insurance policies in which the insured has retained a power to change the beneficiary illustrates this principle. When life insurance policies with express revocation clauses first began to appear, there was some uncertainty concerning the effect of the retained power on the American rule that beneficiaries held a vested right in the policy, that is, a fully protectible property interest. Most of the decisions in the early part of this century held that the status of the beneficiary's interest was the same as that of legatees under wills of living testators. ${ }^{91}$ Vance and other leading commentators endorsed that view, characterizing the interest as an expectancy, and rejected the view that bencficiaries held protectible property interests subject to divestment by the insured alone. They expressly adopted the notion that the insured's retention of unlimited control over designation of beneficiary meant that a designated beneficiary could not be the holder of a present property interest. ${ }^{02}$ This view created conceptual difficulties for various uses to which beneficiaries put their interests, for example, as the subject matter of an inter vivos trust. ${ }^{93}$ As the modern features of life insurance policies became more common, courts adjusted their perceptions of the nature of the beneficiary's interest, classifying it as a defeasible future interest. ${ }^{94}$

Thus, the beneficiary was viewed as having received what I earlier called a purported present transfer with an open-ended contingency. He has been told, "I hereby give you the right to receive certain assets, to be delivered upon my death, unless I decide to give those assets to someone else."

Calling this expectancy a property interest may appear to be an empty gesture: after all, the insured is as free to change the beneficiary of the policy as the testator is to terminate the interest of the prospective legatee. The significance of calling the beneficiary's interest property, however, becomes apparent when his rights against third-party interference are considered. If,

91. E.g., Mutual Benefit Life 1ns. Co. v. Swett, 222 F. 200 (6th Cir. 1915); McEwen v. New York Life ins. Co., 42 Cal. App. 133, 183 P. 373 (1919); Hicks v. Northwestern Mut. Life Ins. Co., 166 lowa 532, 147 N.W. 883 (1914); McGowin v. Menken, 223 N.Y. 509, 119 N.E. 877 (1918).

92. See Vance, The Beneficiary's Interest in a Life Insurance Policy, 31 Yale L.J. 343, 358-60 (1922).

93. Compare Bickers v. Shenandoah Valley Nat'l Bank, 197 Va. 145, 88 S.E.2d 889 (1955), with Gurnett v. Mutual Life Ins. Co., 356 Ill. 612, 191 N.E. 250 (1934); Bose v. Meury, 112 N.J. Eq. 62,163 A. 276 (1932).

94. E.g., Roberts v. Northwestern Nat'l Life Ins. Co., 143 Ga. 780, 85 S.E. 1043 (1915) (vested subject to divestment); Indiana Nat'1 Life Ins. Co. v. McGinnis, 180 lnd. 9, 101 N.E. 289 (1913) (same); Metropolitan Life Ins. Co. V. Woolf, 138 N.J. Eq. 450, 47 A.2d 340 (1946) (same); Hirsh v. Auer, 146 N.Y. 13, 40 N.E. 397 (1895) (contingent). 
for example, the insurance company were to claim that the policy had lapsed, or were to fail to meet its obligation to maintain a reserve fund, the beneficiary would be permitted to bring an action against the insurance company claiming that the company had breached the terms of the policy. Indeed, recent courts, recognizing that it is this set of rights which distinguishes the beneficiary from the presumptive heir or legatee, have again reinterpreted the legal position of the beneficiary, calling him a third-party donee beneficiary of the contract between the insured and the insurance company. ${ }^{95}$

\section{Use-Rights}

1. Retained Use-Interests. In discussing an earlier example involving the transfer of a gas-powered leaf-blower, I suggested that ordinary intuitions commonly recognize the possiblility of simultaneously existing use-rights in the same asset. Thus if $A$ transfers his rake to $B$, stating, "The rake is now yours, but if my leaf-blower ever breaks down, you must let me use the old rake," most laypersons would comprehend the notion that after the transfer, both $A$ and $B$ have an interest in the rake.

There are many parallels to this intuition in the common law. To cite only one example, American courts have long permitted grantors to reserve to themselves easements in land that they simultaneousIy transfer to others. For example, $O$ may convey Blackacre to $A$ reserving to himself a ten-foot wide easement of way across the southeast corner of Blackacre. $A$ holds a fee interest in all of Blackacre, and $O$ simultaneously has a right, albeit limited, to use part of Blackacre. ${ }^{96}$ Both $A$ and $O$ are treated as "owners" of different presently exercisable interests in the same land. Both are accorded legal protection against encroachments upon their respective interests, vis-a-vis both each other and third parties.

The common law also recognizes that it is possible to create by grant interests that are subject to revocation by the grantor. One example of these interests is the license. ${ }^{97}$ Here, the grantee is in the position of one who is told, "I hereby give you this rake, unless I decide to take it back."

For both licenses and easements, present exercise by either party is immaterial in determining the extent to which the use-interest will be protected. An

95. E.g., Gordon v. Portland Trust Bank, 271 P.2d 653, 656 (Ore. 1954).

96. Historically, courts have treated the creation of an easement in favor of the grantor in land conveyed by him as a special case. English courts held that an easement could neither be reserved nor excepted, but to overcome this conceptual obstacle, which they had created themselves, employed the legal fiction that an easement "reserved" was created by a regrant by the grantee to the grantor. Although American courts adopted this regrant theory in early cases, they quickly abandoned the view that easements could not be reserved by the grantor. On the development of easements by reservation, see 2 American Law of Property $\S \S 8.24-8.28$ (A. Casner ed. 1952); Bigelow \& Madden, Exception and Reservation of Easements, 38 Harv. L. Rev. 180 (1924).

97. R. Powell, Powell on Real Property 9 404[il (P. Rohan rev, ed. 1981). 
easement remains effective despite nonuse. ${ }^{98}$ Exercise of a license in no way impedes the grantor's right to revoke. ${ }^{99}$

2. The Nature of the Encroachment. In discussing the nature of ordinary expectations, I maintained that laypersons would make a sharp distinction between encroachments that were physically invasive and those that were not. ${ }^{100}$ This distinction is reflected in the attitudes of the common law towards actions for nuisance, and actions for trespass or conversion. The torts of trespass and conversion protect the interest in freedom from physical invasion and deprivation of possession. ${ }^{101}$ Actions may be maintained, and at least nominal damages recovered, even where the interest holder is not deprived of any use he would otherwise have made of his property. ${ }^{102}$ In contrast, the law of nuisance primarily applied to noninvasive encroachments, ${ }^{103}$ such as noise, ${ }^{104}$ vibrations, ${ }^{105}$ or health-endangering unsanitary conditions ${ }^{100}$ on adjacent land. Nuisance law protects only the interest in use and enjoyment of land, and thus a plaintiff must establish that the activity complained of interfered with some actual use he had made of his land.

3. Third Party Encroachments on Licenses. Recall that, according to my earlier discussion, a layperson would expect that an interest in a physical object subject to an unrestricted right of termination by the grantor might nonetheless be protected against third party encroachments if the terms of the transfer appeared to create a present interest in the transferee. When called on to construe the scope of an interest created by a grantor who retains an unrestricted right to terminate the grantee's interest, how is a court to determine whether or not a purported present transfer of rights, protectible against third party encroachments, has been made? In discussing the structure of ordinary thought, I chose two clearly polar ways of phrasing the grant: "I hereby give you" and "I will give you." Actual grants, however, are seldom worded in a way that makes that task of construction this simple, and a court must generally look to other features of the grant beyond the phrase used to indicate that some transfer is being made. Thus, if present possession strongly strengthens the grantee's claim that he has a property right, it would seem that a grantor who retains an unrestricted right of termination but presently trans-

98. Arnold v. Stevens, 41 Mass. 106 (1839) (grant by deed of right to mine not extinguished after 40 years nonuse); White v. Crawford, 10 Mass. 183 (1813) (easement for right of way not extinguished after 32 years nonuse); Restatement of Property $\$ 504$ comment d (1940); R. Powell, supra note 97, 9 423; E. Washburn, A Treatise on the American Law of Easements and Servitudes 639-42 ( $2 \mathrm{~d}$ ed. 1867) and cases cited therein. Nonuse may be evidence of abandonment, but does not itself establish it.

99. R. Powell, supra note 97, I 422.

100. See supra section II. B. 2.

101. Restatement (Second) of Torts $\$ 222$ (1977) (trespass to chattels); id. $\$ 222 \mathrm{~A}$ (conversion); id. $\$ 158$ (trespass to land).

102. Id. $\$ 222$ comment a; id. $\$ 163$.

103. 1 d. $\$ 821 \mathrm{D}$.

104. See, e.g., Hooks v. Int'l Speedways, 1nc., 263 N.C. 686, 140 S.E.2d 387 (1965). See generally Lloyd, Noise as a Nuisance, 82 U. Pa. L. Rev. 567 (1934). (1948).

105. See, e.g., Sam Warren \& Son Stone Co. v. Gruesser, 307 Ky. 98, 209 S.W.2d 817

106. See, e.g., Mills v. Hall, 9 Wend. 315 (N.Y. 1832). 
fers possession will be likely viewed as having created in the grantee a property right protectible against third-party encroachments.

In fact, however, the common law has sometimes viewed presently possessory interests as nonproperty. For example, the common law distinguishes between two sorts of use-interests, easements and licenses. While easements are conventionally classified as property, the status of licenses has been much less certain. What distinguishes easements from licenses is the latters' vulnerability to unilateral revocation by the grantor. This feature has led to the conception of licenses as interests that are unprotectible against third party interference as well as against the grantor's subsequent revocation. ${ }^{107}$ Illustrative of this conception is Taft $v$. Bridgeton Worsted Co. ${ }^{108}$ In that case, plaintiffs, who were owners of part of the land under a pond created by the defendant's dam, cut ice on the entire pond. The defendant drew down the water at a time when the ice was ready to be cut. The court allowed damages for the injury to the ice over the plaintiffs' own land but not for ice that covered land of a third party who had given to plaintiffs a license to cut. The court said that " $[t]$ he damage to their right to exercise their revocable license was a damage which the law does not recognize as an injury to their property." ${ }^{109}$ Had the plaintiff acquired from the third party an irrevocable right to cut ice on that part of the pond covering the other's land, his interest would have been classified as an easement and in all likelihood would have been deemed protectible against defendant's unreasonable interference.

From a functional perspective, this distinction at first appears anomalous. With respect to third party interference, revocability by the grantor arguably should be irrelevant. That the licensee's interest is extinguishable by the licensor does not necessarily indicate that it is unprotectible against other encroachments. It has value to the licensee, and in cases such as Taft this value is destroyed as much as the value of that part of plaintiff's interest that existed as a consequence of ownership of his land.

The distinction is sometimes justified on "policy" grounds. The policy considerations usually cited in support of cases refusing to protect the liccnsee's interest usually boil down to something that sounds very similar to the de minimis non curat lex maxim. Judge Charles Clark stated in his monograph on covenants:

Admitting that the licensee has only a privilege against his licensor, does it follow that he possesses no rights against interference by third persons? Not necessarily, though the cases, with little dissent, are generally of the opinion that no such rights exist. But the question is one of policy, which in this case would seem largely one of justice and equity, and not of logic. Certain cases might be conceived where recovery by the licensee against a third party inter-

107. See 3 H. Tiffany, The Law of Real Property $\S 829$ (3d ed. 1939) (“That a licensee, as such, has no right of action against a third person obstructing his exercise of the license privilege is, it is conceived, beyond question, in spite of occasional decisions to the contrary.").

108. 246 Mass. 444,141 N.E. 119 (1923), notcd in 33 Yale L.J. 642 (1924).

109. 246 Mass. at 453,141 N.E. at 122 . 
fering with the exercise of his privilege might seem just, but it is suggested that little hardship is caused by the general rule and there is not sufficient ground to urge a change. The interest is so slight, the licensor can so easily destroy it, that probably in the long run it does not justify the time and expense requisite to the setting in motion of the ponderous and creaking judicial machinery for its protection. ${ }^{110}$

It is difficult, however, to justify the failure to protect licenses on the basis of the interest's economic insubstantiality. In some cases the license involved, though revocable at will by the licensor, may have considerable economic significance to the holder. In one case, ${ }^{111}$ for example, the licensee depended on his license to cut ice in order to satisfy requirements contracts obligations of an ice house to whom he had sold ice for several years. Though interference with the license caused him to breach the contracts and to lose profits from supplying ice, the court held that he could not recover for the interference.

The refusal to protect licenses against unreasonable intcrferences by third parties may be explained instead on the basis of the conceptual difficulty courts have had in viewing these intcrests as property. Assuming that injury to a "property" interest is an indispensable prerequisite of recovery against such encroachments, ${ }^{112}$ licenses, as mere revocable privileges to do some act upon the land of another, have not been deemed to rise to the level of property. They are viewed instead as belonging to the same category of "nonproperty" interests as the expectancy interest of presumptive heirs. ${ }^{113}$ As in the case of the expectant heir's interest, their total vulnerability to another person's unrestricted discretion to terminate prevents their recognition as property.

This brief survey of several common-law interests serves to illustrate the tendency of the common law to distinguish between property and nonproperty at a conceptual level. Specifically, the notion that I have traced in these areas-that interests compietely subordinated to another person's power to destroy them are not property-is not simply an expression of various func-

110. C. Clark, Real Covenants and Other Interests which Run with the Land 28-29 (2d ed. 1947). See also R. Powell, supra note 97, 9 428. To realists like Clark, the issue was one of policy, specifically, whether the interests involved were too insignificant to justify legal protection. To the late nineteenth and early twentieth century courts, however, the question of protecting licensees against third-party interference was very much a matter of resolving the abstraet nature of the licensee's interest, in terms of the dichotomy between property and nonproperty. The related forces of conceptualism and systematization led courts at this time to conceive of questions of legal protection as a matter of defining the nature of the interest involved and establishing distinet formal characteristics that would control the categories into which interests would be placed. Thus, it is not surprising that courts would relate together functionally disparate interests like licenses, life insurance, and orthodox expectancies on the basis of the same formal charaeteristics. As I will discuss later, this tendency has not been totally abandoned. See infra text aceompanying notes 114-25.

111. Balcom v. McQuestien, 65 N.H. 81,17 A. 638 (1889).

112. See, e.g., Kavanagh v. Barber, 131 N.Y. 211, 30 N.E. 235 (1892); Sabine \& E. Tex. Ry. v. Johnson, 65 Tex. 389 (1886); Stockport Waterworks Co. v. Potter, 159 Eng. Rep. 545 (Exch. 1864).

113. The analogy is expressly developed in Evans, 1nterferences with Licenses by Strangers, 1 St. Louis U.L.J. 189, 193 (1951). 
tional aims that courts have attempted to promote but have not articulated. Instead this approach represents a distinct conception of property that courts have used to distinguish property from nonproperty interests.

\section{Common-Law and Constitutional Conceptions of Property}

In this section I shall relate the various aspects of the common-law conception of property to distinctions drawn in recent constitutional decisions. I shall argue that the Supreme Court in these cases has resolved the status of interests at issue in modern entitlements and land-use cases by extending and adapting familiar legal ideas from the private-law sphere.

\section{A. Constitutional Protection of Interests in Government Benefits}

The conclusion in Flemming $v$. Nestor that the claimant had no accrued property interest in Social Security benefits can now be seen as consistent with a basic structure of ideas that underlies conventional legal notions about property. The case does not indicate that all of the "new property" interests will be unprotected because of their lack of spatial characteristics. Flemming indicates rather that the basis for distinctions between property and nonproperty with respect to familiar forms of wealth in established private-law doctrines has been carried over to the constitutional setting and applied to heretofore unfamiliar interests in government benefits.

The majority opinion begins by noting that the issue in the case "requires some inquiry into the statutory scheme by which [the general purposes underlying the Social Security Act] are sought to be achieved." 114 Looking at that scheme, the Court placed special emphasis on its method of funding the program. It noted that eligibility for benefits and the amount of benefits do not depend on contributions to the program through payment of taxes but on the earnings record of the beneficiary. ${ }^{115}$ The Court regarded this aspect of the statutory scheme as indicating that the relationship between the government and participating employees is noncontractual in nature. There is no assurance under the statute that all participants, who finance the program through payroll taxes, will receive benefits commensurate with the level of their contributions. Indeed, it is possible that some contributing employees will receive no benefits whatsoever. Their entitlement to benefits depends on satisfaction of several statutory conditions, among which are attainment of the requisite age, employment in covered employment, and coverage under the program for the requisite period of time.

The majority considered this feature of the statutory scheme to distinguish the case from Lynch $v$. United States, ${ }^{116}$ in which it had held that a congressional attempt to cancel war risk insurance policies issued by the government to World War I servicemen was an unconstitutional taking of

114. 363 U.S. at 608 .

115. Id. at 609 .

116. 292 U.S. 571 (1934). 
private property. The Court in Lynch had emphasized that the payment of premiums created a contractual relationship with the government, even though the government did not enter into these contracts for a business purpose. Justice Black, dissenting in Flemming, argued that contributions to the Social Security fund were basically the same as payments of insurance premiums in Lynch. In both cases the programs involved assumptions by the government of burdens, and it was conceded in Lynch that the government did not issue the insurance policies for gain. Since the premiums were considered to be consideration for a legally binding obligation in spite of the quasigratuitous nature of the program in Lynch, Justice Black argued, employee contributions to the Social Security scheme should be seen to create enforceable obligations despite the method of funding the program.

The majority in Flemming viewed the contributions as essentially no different from payments of a general revenue tax. The Court pointed out that the statute provides that the tax proceeds are paid into the Treasury "as internal-revenue collections." To be sure, the proceeds are not mixed with general revenue funds or used to finance other government services, but the evident nature of the payments by contributors is as a tax, rather than as consideration for a promise by the government. Just as payment of a general income tax does not entitle one to provision of particular government services, so payment of the payroll tax does not create an entitlement to future Social Security benefits. That tax does not buy such benefits any more than the income tax buys a certain measure of national defense.

Assuming that the Court was correct in viewing contributions to the Social Security program as not creating an enforceable contractual obligation on the part of the government to pay future benefits, it does not necessarily follow that recipients of Social Security benefits have no property interest in the stream of future benefits. Suppose that the government in effect told contributors, "We hereby transfer to you the right to monthly cash payments to begin upon your attaining age sixty-two or your total disability, whichever occurs first, of an amount which will depend upon your earnings record, subject to reduction or termination if you earn more than a specified amount after benefits have begun to be paid to you." The effect of such a statement would be that the government has made a gift of a conditional future interest in cash benefits, an interest recognizable as property. Recipients would have an enforceable right to continued benefits, even though they had paid no consideration, because a present passing of an interest to the recipients would have occured.

The fact that prevented the conclusion that the Social Security Act passed a property interest to Nestor was not the gratuitous nature of the program but the government's express reservation of the right to alter, amend, or terminate the program. ${ }^{117}$ The effect of that provision was to deny any continuing obligation to make benefit payments. Benefits were paid to Nestor as a series

I17. 42 U.S.C. $\S 1304$ (1976). It was pursuant to this provision that $\S 202(n)$, the statute under review in Flemming, was enacted. 
of discrete completed gifts, rather than as gradual possessory realization of a present right to future enjoyment. When the government terminated his benefits, then, it was not divesting an interest already transferred to him or taking away something that he already had, but rather was failing to give him something that he desired, or perhaps expected in a subjective sense, but which he did not presently have.

The notion that the reservation of the power to revoke or alter the program implied that no participant could have an accrued property interest in future benefits represents an adaptation of the private-law idea that I examined earlier. The government had the power to prevent any participant from possessing or enjoying proceeds from the Social Security trust fund. Thus, Nestor's interest in future benefits, like the interest of a presumptive heir in his ancestor's estate, was totally subordinate to the unrestricted power of another person. This is the type of arrangement in which the common law has been inclined to hold that the interest held by the claimant is not property. We do not need to rely on a reified "thing" conception of property to explain the Court's view that Nestor was not vested with a property interest. We need only examine the conditions, specified in the statute, on his right to present enjoyment to see that in terms of existing legal conventions Nestor had only an expectancy in future benefits.

This is not to say that applying the conceptual outlook that underlies the private law distinctions will leave all of the "new property" interests without constitutional protection. The recent series of "entitlement" cases indicate that for procedural due process purposes some of the newer intercsts will probably be protectible as property. Many commentators believe that these cases indicate a rejection by the Supreme Court of traditional notions about property and nonproperty, and thus seriously undercut the holdings of earlier cases such as Flemming. ${ }^{118}$ Basic similarities, however, can be found between the formal characteristics of those interests and the interest involved in Flemming $v$. Nestor, suggesting that the conception of property used in the more recent entitlement cases is essentially the same as that at work in Flemming, even though the entitlement cases raised the question of wcaker procedural protection while the claimant in Flemming sought substantive protection.

In Perry v. Sindermann, ${ }^{119}$ for example, the Court held that a cause of action was made out by a state college professor who claimed that he had been denied procedural due proccss by the failure of the college to grant him a hearing prior to deciding not to renew his contract. The majority found that the claimant might be able to establish that he had a property interest in

118. Professor Tribe, for example, stated that

[t] he body of rules detcrmining which expectations constitute compensable property interests and which do not, see, e.g., Flemming v. Nestor, 363 U.S. 603 (1960) . . ., plainly requires reconsideration in light of the broader definition of property interests now employed in the law of procedural due process .... There seems no good reason why the broader definition should not be extended to the takings eontext.

L. Tribe, supra note 22 , at 459 n.11.

119. 408 U.S. 593 (1972). 
renewal of his contract because there existed evidence of "an unwritten 'common law' . . that certain employees shall have the equivalent of tenure."120 This conception of property certainly does not conform to the ordinary understanding that Professor Ackerman describes, but it is consistent with conventional legal ideas since it focuses on the question whether the state employer had expressly or informally made a commitment to its teachers to maintain the employment relationship. The absence of such a commitment, not the unfamiliarity or abstractness of the interest, caused the Court in Flemming to find that Nestor's interest in future Social Security benefits was not property.

Viewed in this light, Nestor's interest resembles interests that the Supreme Court more recently has held not to rise to the level of protectible property for procedural due process purposes. In Board of Regents $v$. Roth, ${ }^{121}$ for example, the Court found that no property interest was affected when a state university failed to retain a probationary, untenured assistant professor. Unlike the situation in Perry $v$. Sindermann, the effect was not to terminate a subsisting relationship but only to fail to establish a new relationship like the first. There was no statute or representation to the effect that the employee would continue his employment unless some event, not within the total control of the state, occurred. Consequently, there had been no passing of a future interest in continued employment to Roth, only a discrete, one-year relationship and the expectancy of a future transfer.

Similarly, in Bishop v. Wood, ${ }^{122}$ the Court found that the Roth requirement of a vested subsisting relationship had not been met where a local ordinance, as interpreted by the District Court, provided that the claimant, " "held his position at the will and pleasure of the city." "123 In that case the claimant was a local policeman who alleged that as a permanent employee within the meaning of the relevant local ordinance, he was deprived of a property interest in his job without due process when the city discharged him without a hearing. The Court held that the discharge did not deprive him of a protectible property interest since under the ordinance his employment was terminable at will. Assuming that the interpretation given to the ordinance was correct, ${ }^{124}$ it had the effect of expressly denying that any right to a future interest in his job had been transferred to the claimant.

In both of these cases, the Court appeared to say that where the government, as the source of the interest in question, retains unrestricted discretion

120. Id. at 602.

12I. 408 U.S. 564 (1972).

122. 426 U.S. 341 (1976). See Van Alstyne, Cracks in "The New Property": Adjudicative Due Process in the Administrative State, 62 Cornell L. Rev. 445 (1977) (discussing how Bishop v. Wood opened the back door to the right/privilege distinction).

123. 426 U.S at 345 .

124. 1 suspect that most laymen would be surprised by the interpretation placed upon this ordinance, just as they would be surprised by the construction of the Social Security statute adopted in Flemming. See Monaghan, supra note 16, at 439-42; Van Alstyne, supra note 122, at 467-69. 
over the future of the interest, then the interest is not a protectible entitlement. The Court has extended this line of reasoning more recently to cover other interests growing out of individual relationships with the State. In Memphis Light, Gas \& Water Division v. Craft, ${ }^{125}$ for example, the Court held that customers of a public utility had a property interest in continued service because state law did not permit a utility to terminate service "at will" but only "for cause."

This line of analysis, emphasizing the at-will/for-cause distinction, supports the significance in Flemming of the clause reserving to the government the right to alter or terminate any provision of the Act. Like the employment relationships involved in Roth and Bishop, a Social Security recipient's interest in benefits is terminable at will. This feature of the program precludes the existence of a subsisting interest in the stream of future benefits and helps to explain what the Court meant in stating that Nestor had no "accrued property right" in future benefits and why it took that view.

\section{B. Land-Use Regulations}

The same feature-the existence of a retained power in another to block completely any possibility of future use or to terminate present enjoymentcan be used to explain cases involving more familiar sorts of interests that are detrimentally affected as a consequence of governmental land-use restrictions. For example, in United States v. Twin City Power Co. ${ }^{126}$ the Court held that when riparian lands were appropriated by the Unitcd States as part of a river development project, the riparian owner was not entitled to any compensation for the loss of his actual or prospective exploitation of the flow of navigable waters, even though the government's action clearly resulted in a reduction of the economic value of the owner's land. The Court relied upon the "navigation servitude" of the United States as the basis for denying that riparian owners have a justified expectation of protection against government encroachments upon their exploration interests in navigable waters. The theory seems to be that when the government, formally or otherwise, reserves the right to preempt the exploitation of a particular class of resources at any time, it has in effect warned actual and potential exploiters of possible future actions that will cut off the opportunity to exploit. Given this prior warning, claimants can have no justified expectation of protection against government action. Compensation is not required when such actions are taken because there has been no taking of any "property" interest under these circumstances. ${ }^{127}$ The "property" characterization is blocked for essentially the same

125. 436 U.S. 1 (1978).

126. 350 U.S. 222 (1956).

127. The Court has adhered to this reasoning not only in cases dealing with government expropriation under Congress's commerce clause authority to regulate the "navigable waters" of the United States, see, e.g., United States v. Rands, 389 U.S. 121 (1967); United States v. Kansas City Life Ins. Co., 339 U.S. 799 (1950); United States v. Willow River Power Co., 324 U.S. 499 (1945); United States v. Cress, 243 U.S. 316 (1917); United States v. Chandler-Dunbar Water Power Co., 229 U.S. 53 (1913), but also on other occasions, see, e.g., United States v. Miller, 317 
reason as it is in Flemming-the claimant's interest has formally been made subordinate to the state's power to extinguish the interest. In ordinary terms, the prior warning of possible action that extinguished all opportunity of benefit or enjoyment makes the claimant's interest fundamentally indistinguishable from that of someone who buys a losing lottery ticket-no more than an expectancy or possibility of future benefit.

The majority of decisions that evaluated whether constitutional protection should be accorded to interests in government benefits turned on whether the government had implicitly reserved the right to terminate those benefits; in contrast, in the majority of land-use cases, the government's role was that of a third party encroacher, who had taken no part in the initial allocation of property rights.

Perhaps the most famous land-use case under the takings clause is Pennsylvania Coal Co. v. Mahon. ${ }^{128}$ There, the plaintiff coal company had transferred the surface rights to land it owned to another party, while retaining the right to mine the subsurface coal. The Pennsylvania state legislature enacted a statute regulating coal mining that in effect barred all future mining of coal by the plaintiff. The plaintiff had not, prior to enactment of the statute, attempted to exercise its right to mine the coal. When the coal company brought an action for compensation under the takings clause, the Supreme Court found that the company had indeed suffered a compensable taking.

To Ackerman, Pennsylvania Coal represents the crisis of Ordinary Observing. He maintains that the Supreme Court was able to find the coal company's interest protectible only by implicitly abandoning the ordinary premises it had traditionally applied to takings clause cases. While it cannot be denied that Pennsylvania Coal is an innovative constitutional decision, it is in fact a far less radical departure from traditional methods than Ackerman would have us believe, and one which is entirely consistent with both the goals and the more general conceptual apparatus of Ordinary Observing.

Ackerman believes that the significance of Pennsylvania Coal derives from the fact that the use-interests for which compensation was awarded had not been exercised at the time the regulation was enacted. The Supreme Court, he maintains, departed from its Ordinary premises by treating legal property as if it were social property. It did so, moreover, in a way that created a hybrid monster that was neither Ordinary nor Scientific. The Court's emphasis on the status of the easement under Pennsylvania law suggested that it would not have awarded compensation had the property remained undivided in the coal

U.S. 369 (1943) (compensable value of interest in land appropriated for federal highway project does not include that part of current market value of the land due to government's announcement of its selection of the land as site for its project). The theory recently resurfaced in arguments made, but rejected by the majority as inapplicable under the facts, in Kaiser Aetna v. United States, 444 U.S. 164 (1979). Justice Blackmun's dissenting opinion in the Kaiser Aetna case appears to be grounded expressly on this theory, when he states, "[T]he developers of Kuapa Pond have acted at their own risk and are not entitled to compensation for the public access the Government now asserts." 1d. at 190.

128. 260 U.S. 393 (1922). 
company's hands, a result inconsistent with both the Ordinary and Scientific frameworks. ${ }^{129}$ The Scientist views the right to mine possessed by the holder of an undivided interest as prima facie protectible as the right of the holder of a divided interest; the Ordinary Observer views the difference in treatment as a breach of the principle of parity, long established in the common law, that compensation paid to the holders of a set of divided interests should be exactly equal to that which would be paid had the property been held in fee simple.

By itself, the award of compensation for a taking of an unexercised useinterest signalled no departure from either prior law or the layperson's conception of property. Compensation had been awarded in earlier cases for takings of unexercised use-interest and these cases had aroused no controversy. ${ }^{130}$ These results seem natural once it is understood that the terms by which an interest is created, and not. merely the fact that the interest is physically embodied in a document, give rise to ordinary expectations. Ackerman's assertions to the contrary seem to rest on the belief that only lawyers have been given the gift of language.

Where Pennsylvania Coal does depart from prior law is in its award of compensation to an unexercised use-interest that had been impaired by a noninvasive governmental action. ${ }^{131}$ The Commonwealth of Pennsylvania had not seized the mine, nor even physically entered onto it. Noninvasive encroachments-both ostensible exercises of the police powers ${ }^{132}$ and nuisancelike acts of the State or its agents ${ }^{133}$ - had previously been held to be takings, and the weight of commentary favored extension of this principle as early as $1874,{ }^{134}$ but the interests compensated appear to have been exercised. Even

129. B. Ackerman, supra note 8 , at 163-67.

130. See, e.g., Lime Rock R.R. Co. v. Farnsworth, 86 Me. 127, 29 A. 957 (1893).

131. This is the result, for example, in Village of Euclid v. Ambler Realty Co., 272 U.S. 365 (1926), where the Court upheld against a fourteenth amendment due process clause challenge, a local zoning ordinance forbidding certain commercial uses of appellee's land, even though the restriction resulted in a $75 \%$ diminution of the land's value. See also Transportation Co. v. Chicago, 99 U.S. 635 (1878) (common law of eminent domain); Legal Tender Cases, 79 U.S. (12 Wall) 457 (1870) (takings and due process clauses of fifth amendment).

132. See, e.g., Dobbins v. Los Angeles, 195 U.S. 223 (1904) (due process clause of fourteenth amendment barred zoning change). See generally 1 Lewis on Eminent Domain $\S \S 243,245$ (3d ed. 1909).

133. See generally 1 Lewis, supra note 132, $\S 229$ (blasting); id. at $\S 235$ (noise, smoke, vibrations, etc. caused by operation of railroad); id. at $\S 236$ (polluting the atmosphere); id. at $\S$ 238 (general); Wood on Nuisances $\S 755$ (1st ed. 1875).

134. Sedgwick, Constitutional Law 462-63 (2d ed. 1874); 1 Lewis, supra note 132, §§ 62-66. Lewis's commentary is particularly interesting, for it defends the protection of indirect encroachments on use-interests by appeal to the layperson's conception of property.

The dullest individual among the people knows and understands that his property in anything is a bundle of rights. . . . Although, as Austin says, all men speak loosely of things as property yet practically all men understand that property consists of certain rights in things which are secured by law. They constantly act upon this understanding, although they may never have formulated a definition of the word and would be at a loss to do so .... . Now it seems to us that the word property in the constitution should be given a meaning which, while in accord with the sense with which it is practically used and understood by the people, will also secure to the individual the largest degree of protection against the exercise of the power intended to be restricted.

1d. at $\S 64$. 
this line between invasive and noninvasive encroachments had become blurred. Compensation to the holders of unexercised use-rights had been awarded in cases where the state had not seized the interest in question, but had merely obstructed access to it. ${ }^{135}$

In extending takings clause protection to clearly noninvasive encroachments on unexercised use-interests, the Pennsylvania Coal Court seized on a feature of ordinary thought that Ackerman mistakenly characterizes as reification. The scientific conception, building upon the notion of property as bundles of right, is essentially reductionist. It conceives of every right within the relevant bundle as a protectible interest. The ordinary conception, by contrast, is unitary. Ordinary thought does not seem to reduce the bundle to its constituent elements. The idea of isolating a discrete use-right from the collective bundle appears to be alien to ordinary habits of thought. The bundle is irreducible, and it is the entire bundle itself that is viewed as property. But bundles need not be defined in reified "thing"-terms. They may be divided and new bundles, consisting of use-rights formerly held as part of more comprehensive bundles by one person, can be granted to others.

In the ordinary view, however, some "crystallization" is needed to establish the existence of the divided bundle. ${ }^{136}$ Since words, as well as actual use, had been used to crystallize interests against invasive encroachments, despite the absence of present use, it was but a small step to extend this principle to indirect encroachments. Ordinary intuitions about crystallization, however, dictatèd a difference in treatment between fees simple and divided interests. Because of the importance of possession in ordinary intuitions, a fee simple deed may have seemed sufficient to crystallize the right to exclusive possession but nothing more. A document specifiying a particular use, however, crystallized an interest in that particular use. Thus, the supposed Ordinary anomaly in the different treatment of divided and undivided use-interests disappears. Indeed, this ordinary idea of crystallization had to some extent been recognized with respect to the issue of compensation in earlier takings law. The principle of parity to which Ackerman refers was indeed a majority rule, but it was by no means without exception. ${ }^{137}$

To the extent that Pennsylvania Coal marks a change, it is one that is entirely consistent with the ideological foundations of Ordinary Observing that will be discussed in the next Section.

135. United States v. Welch, 217 U.S. 333 (1910); Lime Rock R.R. Co. v. Farnsworth, 86 Me. 127, 29 A. 957 (1893); People v. Eldrige, 6 Thomps \& C. 20 (N.Y.).

136. It may be worth noting that this distinction, however unsophisticated it appears to scientific minds, finds parallels in other areas as well, reflecting the pervasiveness and powcr of ordinary thought over legal theory generally. For example, as the famous paper by Fuller and Perdue on contract damages, Fuller \& Perdue, The Reliance Interest in Contract Damages, (pts. 1 \& 2), 46 Yale L.J. 52, 373 (1936-1937), and P.S. Atiyah's recent book on the history of contract theory, P. Atiyah, The Rise and Fall of Freedom of Contract (1979), discuss, out-of-poeket losses, representing a reliance interest, traditionally have been considered more easily compensable then opportunity costs, the so-called expectation interest. Aside from other reasons for this tendency, it may be possible to explain this distinction in terms of losses of existing expenditures as losses of discrete, crystallized bundles of property.

137. Nichols on Eminent Domain, § 12.36[2] (1981). 
These cases indicate that courts have been able to accommodate new legal phenomena within the existing legal conception of property. When courts have refused to extend constitutional protection to unconventional interests, it has not been because the interests lack requisite spatial characteristics of more familiar forms of property. That is, refusal to find these interests prima facie protectible has not been due to the inability to say that they are things that were taken, but rather from the perception that they are totally subordinate to another interest and, as such, constitute as-yet-uncrystallized expectations. Consequently, Ackerman's explanation of refusals to extend constitutional protection to certain of the "new property" interests in terms of their lack of reification seems inaccurate. The conceptual view implicit in these cases is not oriented by a crude thing/person relationship but by more abstract characteristics, such as the presence of a power in the person or entity from whom the interest derives unilaterally to extinguish all opportunity for the interest holder to obtain or continue enjoyment of the asset.

\section{The IDEology of the OId AND New Property}

In this section I shall argue that the tendency in ordinary and commonlaw thought to treat as nonproperty those interests which, if protected, would dilute control held by another person can be linked to traditional liberal values. The ordinary mode of analyzing the status of claim-interests as property can then be understood not as an isolated conceptual structure but as integrally related to a distinct moral and political ideology, liberalism. This suggests reasons for the emergence of the so-called scientific mode of analyzing claims to constitutional protection of private interests other than the methodological reasons that Ackerman discusses. The shift has been made in order to avoid the anomalous results of applying the conceptual structure of ordinary thought and common-law doctrines to previously unknown interests in government-derived benefits, results that, as Flemming v. Nestor illustrates, are at odds with the implicit ideology of the established legal and ordinary conception, with its tendency to concentrate control over assets by treating subordinated interests as non-property.

\section{A. The Rise of the New Property: Ackerman's Explanation}

Using his account of the differences between the two approaches to the concept of property, Ackerman develops a thesis concerning the analytical power of the two competing models of adjudication, Ordinary Observing and Scientific Policymaking. From this thesis, he draws his explanation for why Scientific Policymaking arose when and as it did.

Ackerman's account represents an important revision of the popular legal realist explanation for the decline ${ }^{138}$ in importance of the classical legal con-

138. See Grey, The Disintegration of Property, in Nomos XXII, Property 69 (J. Pennock and J. Chapman eds. 1980) (asserting that property is no longer an important category in legal and political theory). 
cepts such as property. The realist position is that the classical concepts fell into well-deserved disuse when it was recognized that these concepts are inherently indeterminate and thus can have little or no influence on the resolution of substantive questions. ${ }^{139}$ Any distinctions that these concepts ostensibly compelled, the realists argued, were in fact not based on the concepts themselves but on exogenous factors, such as the judge's psychological profile, or widely-shared social goals. Thus, the realists denied that concepts like "property" can play any meaningful role in legal analysis.

Ackerman's account is revisionist because it does not deny altogether that concepts are or can be relevant decisional factors. He implicitly rejects the assertion that the concept of property is inherently ambiguous or indeterminate. Conventional legal analysis does not involve, as the realists suppose, reasoning deductively from universal concepts to particular implications. The classical concepts, rather than being universals, are in fact culturally based, ${ }^{140}$ and their meaning depends on common social understandings, as reflected in ordinary language use. The common perceptions derived from dominant social behavior have in the past provided a more or less objective standard for determining on which side of the line between property and nonproperty a given interest falls.

But, Ackerman believes, although the Ordinary concept of property has been in the past a satisfactory analytic tool, it has some important limitations. Ordinary Observing is analytically weaker than Scientific Policymaking because it relies on a conception of property that loses all force when it must deal with interests that are not somehow spatially manifested. The Ordinary Observer will not be able to analyze claims involving these abstract interests, which Ackerman calls legal property or "lawyer's things," on the basis of his own methodological premises. He will either have to switch to some form of Scientific Policymaking when dealing with legal property claims or "devise an Ordinary-looking solution and suppress the perception that the Ordinary forms are no longer rooted in social-as distinct from legal-practice."141

Now, assuming that Ordinary Observing were otherwise a desirable method of adjudication, this limitation on its conception of property would not seriously weaken the case for Ordinary Observing if legal property represented a small and relatively insignificant segment of economic interests litigated in takings claims. Using Ackerman's criterion for distinguishing legal from social property, ${ }^{142}$ legal property includes interests in the present use or

139. For a discussion of this view, see Kennedy, Form and Substance in Private Law Adjudication, 89 Harv. L. Rev. 1685, 1731-37 (1976), and the sources cited therein. Especially revealing discussions of the concept of property in particular are Philbrick, Changing Conceptions of Property in Law, 86 U. Pa. L. Rev. 691 (1938), and Cohen, Property and Sovereignty, 13 Cornell L.Q. 8 (1927).

140. This distinction is analogous to the philosophical distinction between providing a real definition of concepts and a weaker, nominal definition. The latter approach is not based, as the former is, on the preanalytic meaning of the term under consideration and it avoids the sense of philosophical essentialism that is inherent in the notion of real definition. For an introduetory discussion of these matters, see R. Sartorius, Individual Conduct and Social Norms 35-50 (1975).

141. B. Ackerman, supra note 8 , at 163 .

142. See supra note text accompanying notes 39-49. 
enjoyment of incorporeal assets, such as airspace and mining rights, at least until those rights are manifested by some observable human activity such as actual mining operations. ${ }^{143}$ It also includes interests in the future use or enjoyment of assets. ${ }^{144}$ By definition, these interests are not evidenced by an observable pattern of human interaction. They remain purely abstract, and consequently fall outside the layman's reified conception. To be sure, these interests have been involved in takings litigation in the past, but perhaps they are not sufficiently numerous to create serious doubts about Ordinary Observing. They represent marginal rather than mainstream claims.

Other abstract interests, however, have assumed a nuch greater significance in modern society, and it is the emergence of claims involving these interests that presents the serious challenge to Ordinary Observing. These are interests growing out of various government social programs. They include welfare payments, Social Security disability benefits, public employment, unemployment compensation, and the gamut of other individual interests that Charles Reich labeled "the new property." Anıong then of course are the oldage benefits that Nestor argued were protected by the due process clause. Interests such as Nestor's, Ackerman maintains, are legal property, or at least potential legal property ex ante, though they are clearly not social property. ${ }^{145}$ Had the Suprene Court in Flemming conceived of property more abstractly, using the lawyer's bundle-of-rights metaphor, the initial question, property vel non, would have been unnecessary, or, at the very least, Nestor's interest would clearly have qualified as property.

Ackerman cites Flemming $v$. Nestor as the "great case"146 that exemplifies "the deep methodological difficulties an Ordinary Observer encounters in conceptualizing the 'legal property' problem"' 147 presented by claims to constitutional protection of interests in Social Security and other welfare programs. ${ }^{148}$ As a result of the growing importance of new forms of wealth, Ackerman maintains,

[t]he Ordinary judge is simply without the analytic means to assess the constitutional significance of the great sea change that has transformed property in the twentieth century. Instead, he is confronted with two unsatisfactory options: on the one hand, he may simply reserve the takings clause to social property only, consigning the new property and its protection to constitutional limbo; on the other hand, he may approach the new legal phenomena obliquely by indulging in strained analogies to the older social forms which his chosen method so powerfully illuminated. ${ }^{149}$

The nature of the interest involved in modern property litigation is alien. to the orientation of ordinary thought. This has created the need for an

143. B. Ackerman, supra note 8 , at 121 .

144. Id. at 123 .

145. 1d. at 165,268 n. 115 .

146. Id. at 268 n. 115 .

147. Id. at 269.

148. Id. at 165 .

149. Id. at 166 . 
alternative conception of property that abandons ordinary thought as the standard for evaluating the status of interests, whose protection against encroachments is sought. The modern conception that has emerged to meet this need is a "scientific" conception that is overtly teleological and systematic. Charles Reich's argument, stimulated in part by Flemming, that such interests be protected as "the new property," represented, according to Ackerman, an effort to move constitutional analysis from the conventional, "ordinary" mode to a "scientific" mode in order to overcome the methodological deadend that confronts the ordinary conception of property when dealing with interest in government benefits. ${ }^{150}$

\section{B. The New Property: An Ideological Explanation}

It seems beyond dispute that the rise of the activist state and the increasingly important social role played by government benefits provided the impetus for the development of the teleological mode of analysis. But although Ackerman correctly identifies the cause, he misunderstands the causal mechanism.

Rather than demonstrating the impotence of the conventional mode to analyze the status of such interest, Flemming represents, as I have demonstrated earlier, ${ }^{151}$ an extension of the conceptual structure of both conventional common-law property doctrine and ordinary thought to nontraditional forms of wealth. The Court's analysis in Flemming can be interpreted as compatible with the conceptual structure embedded in several common-law doctrines, including the characterization as "expectancies" of the interests of presumptive heirs under statutes of intestate succession and other interests that at some point have been given that description and treated as nonproperty. At a purely formal level, the analysis is also consistent with the conceptual structure of ordinary expectations as I have described them. By emphasizing the noncontractual nature of the Social Security program and the express reservation in the statute of Congress's right to alter, amend, or terminate the program, the Court characterized the representation made by the statute as in effect stating to recipients: "Transfers of benefits to you now are made without any continuing obligation to make payments in the future, and we will give you benefits in the future unless we choose at any time and for whatever reason not to transfer any of the funds to you." 152 Nothing here purports presently to transfer to Social Security recipients even an abridged ownership interest in future benefits. The representation provides recipients no basis upon which to object to any action that Congress might take to terminate their benefits; Congress, the source of the interest, expressly reserved the power unilaterally to extinguish the beneficiary's opportunity for future enjoyment

150. 1d. at 269 n.115.

151. See supra text accompanying notes 114-125.

152. This is essentially the interpretation that the Court in Bishop v. Wood, 426 U.S. 341 (1976), placed on the terms of the petitioner's employment relationship with the city. 1d. at 344-45. 
of benefits. In effect, then, the Court construed the statute in such a way that no one participating in the program could say, "I have an interest in the fund from which benefits are paid." They can only make the weaker statment, "I am interested in the fund."

The consistency between the analysis in Flemming and that of private law and ordinary thought exists, however, only at an abstract conceptual level. What Reich recognized, and what sets his "scientific" mode of analysis apart from the conventional mode, is that at a teleological level, Flemming contradicts the substantive ethic that is embedded in both ordinary expectations and common-law property doctrines. The theory of "the new property" was developed not because of a perceived inability of the conventional conception of property to yield determinate answers in the context of claims involving government benefits, but because of the paradox that the conventional conception, when applied in cases like Flemming, yields results that contradict the substantive values underlying traditional private-law doctrines.

I suggested earlier that an evident tendency runs through both ordinary expectations and common-law doctrines, such as the "expectancy" characterization of various interests, to concentrate control over the use of each particular asset in a single entity. ${ }^{153}$ This tendency can be explained as related to and at least in part the product of ${ }^{154}$ traditional liberal notions of the role of private property in a legal system. It represents a rejection of an alternative ethic that emphasizes notions of sharing and sacrifice. ${ }^{155}$ Liberalism conceives of the function of law as identifying and enforcing a system of formed rights that create zones of individual autonomy from arbitrary collective or individual power. The condition of individual liberty is considered desirable because it enables people to pursue their own conceptions of the good to the best of their abilities. Within this general scheme, concentration of private control over the use of economic resources in a single individual or entity is ultimately beneficial because it clarifies what conduct with respect to resources, and by whom, is permissible. The economic theory supporting such concentration of control in individuals rather than nonconsensual sharing and sacrifice is that it creates incentives for individual use of resources that maximize their value, with the goal of maximizing aggregate social welfare. The political expression of this view considers the alternative notion of sharing to present risks of the greater evil of intolerance and oppression inherent in a collectivist conception of property.

An individualist conception, which concentrates control in private hands, necessarily means that in the process of drawing boundaries for the purpose of protecting private interests, distinctions have to be made between protectible and nonprotectible interests. If all claims to be the user of resources were

153. See supra text accompanying notes 54-61 \& 62-95.

154. But see Donahue, supra note 36 , at 44 ("Possessive individualism and liberalism may have had considerable influence in furthering the [agglomerativel tendency in the law, but any explanation of the tendency must seek its origins outside those ideas.").

155. See generally Kennedy, supra note 139 . As an ideal ethic, sharing may require only a fair distribution of total wealth, according to a weak conception; according to a stronger conception, it may require socialization of control over individual assets. 
recognized as equally valid, conflicts involving claims to inconsistent uses would increase and threaten the ideal of individual autonomy. The loss of legal protection as to certain subjective claim-interests means, however, that as to other interests one is entitled to receive full legal protection.

The tendency to classify as nonproperty claim-interests that are formally subordinated to another interest can be explained against this background. The status of claims as involving property or nonproperty on this view is determined at a formal level. Recognition of the interest as property depends upon the character of the source of the interest. Protectible property interests cannot be unilaterally created. They depend upon recognition from a source which itself has recognized authority to create protectible entitlements with respect to the asset in question. In mature liberal legal systems this source usually is an individual or entity that is conventionally accepted as the owner. In order to establish the character of another person's claim-interest in some asset as property, then, the claimant must point to some representation by the source that indicates an intention to part with some degree of control over the use or enjoyment of the given asset. If the representation is such that the source retains all measure of control over the asset, then all other interests remain subordinate to the source and lacking any formal basis for recognition as protectible against the actions of the source.

The conventional legal classification of the interest of potential heirs with respect to their ancestors' estates illustrates this theory. If presumptive heirs were considered to have a property interest in the assets that are part of their ancestors' estates, the effect would be a loss by the ancestors of their ability to control the use of their assets during their lives. Ancestors would be "owners" of their assets in a very different sense than we now recognize. Ownership would achieve a decidedly more collectivist sense than it conventionally has in our system. Unless an ancestor has expressly and formally recognized the interest of an expectant heir, by way of a sort of inter vivos transfer, the only other basis for recognizing expectant heirs as having a property interest in their ancestors' assets is the statute that prescribes the pattern for intestate wealth succession upon death. But these statutes conventionally have not been regarded as creating property interests in expectant heirs during the ancestor's lifetime precisely because the effect of doing so would be inconsistent with our standard assumption about what it means to be an "owner" of some asset. With respect to action taken by an ancestor during his lifetime, therefore, expectant heirs are considered to have no protectible interest, only a possibility of future ownership.

As long as claims to protection involved interests that derive from private sources, analysis of the status of claims on the basis of the abstract principle of subordination was consistent with basic liberal premises. It was consistent with the aim of creating spheres of individual autonomy that ultimately meant greater protection against unwarranted collective intrusion. When applied, however, to the problem of evaluating the status of claim-interests that derive directly from the government as the source, this abstract conception of nonproperty led to results that threatened to undercut the substantive ideal of 
individual autonomy. Charles Reich viewed Flemming $v$. Nestor as an example of this contradiction. ${ }^{156}$ To classify as non-protectible those interests which are formally subordinated to the control of the source of the interest meant, in Flemming, that by expressly reserving the power to control the benefits the government could create a system of benefits paid directly to individuals without creating any basis for protection of those individuals against subsequent actions taken by the government as to its benefits. That recipients might be completely dependent upon Social Security benefits was, according to the traditional conception, irrelevant in determining whether the beneficiaries' interests were protectible as property. Government-derived benefits of this sort now comprise the dominant source of wealth for a substantial segment of the community. Since the government is permitted to allocate these benefits on its own terms, individuals are increasingly left at the mercy of the exercise of government discretion, incorporated as a limitation on the entitlement created. The effect was to undermine the individualistic values of personal security and individual autonomy that underlie the traditional conception and the principle of subordinated interests. As the Social Security statute in Flemming illustrated, interests in government benefits could easily be formally subordinated.

To satisfy the substantive values of the traditional conception of property, Reich and other liberals recognized that the abstract conceptual structure, applied in Flemming, had to be abandoned. Specifically, the traditional notion that subordinated interests remained nonproperty, regardless of how important they were to claimants as sources of economic support, had to be eliminated when evaluating the status of this new class of interests. Reich urged that those forms of government largesse that are closely linked to status be deemed to be held as a matter of right. Interests in welfare benefits, professional licenses, and similar sorts of dependency-related wealth should be considered as "vested." 157 In the context of procedural due process claims, arguments have been made that the status of an interest as a protectible entitlement should not depend on the terms of its formal, positive source such as statutes or contracts, as it does according to the analysis developed in Board of Regents v. Roth and Bishop v. Wood, but upon considerations of need. ${ }^{158}$

Taken together, these arguments do represent a decidedly different mode of analysis and conception of property than that employed in Flemming, but at the level of ideology it is altogether consistent with the traditional conception. The "scientific" mode of analysis departs from the traditional mode by freeing the substantive values underlying the traditional conception from the conceptual abstraction used in making private-law distinctions and evaluating the question of constitutional protection directly on the basis of those values. The conceptual abstraction, in other words, has been abandoned in order to

156. Reich, supra note 14 , at 774 .

157. Id. at 785 .

158. See sources cited supra note 220 . 
preserve the same liberal values of individuality and autonomy. In a sense, then, the scientific mode of analysis, exemplified by the "new property" argument, is an extension of Realist methodology and ideology. Its overt instrumentalism and its emphasis on reform are consistent with the Realists' skepticism of abstract conceptualism and commitment to progressive law reform. Like the Realists, who also stressed the need to substitute a "scientific" approach to legal analysis, ${ }^{159}$ the new scientists have been motivated to revise the established conceptual apparatus in order to salvage the liberal ideal of individual autonomy from disintegration in the modern welfare state, into state control and domination. Rather than manifesting a purely methodological crisis, then, the emergence of this latter-day form of Realism indicates the continued domination of liberal beliefs in legal theory and the constant need of liberal legal theory to manipulate its conceptual structures in order to continue to serve its ideological foundations.

\section{Conclusion}

Professor Ackerman's thesis may perhaps be best explained in terms of the recent hypothesis of the nature of changes in the history of ideas developed by Thomas Kuhn. Kuhn attributed scientific revolutions-Copernican, Newtonian, Einsteinian-not to new discoveries, but to a "pronounced failure in the normal problem solving activity." 160 It might be supposed that in legal "science," there are occasions when external events precipitate changes in paradigms of legal thought. As social or economic conditions change, elements of the existing conceptual apparatus of legal analysis become increasingly strained and eventually are unable to accomodate the new phenomena. A new conceptual structure replaces the conventional set of ideas as the dominant mode of thought. Ackerman supposes that aspects of the modern welfare state-increasing reliance by individuals on government-derived wealth and increasing government regulation of the use of economic resources-are catalysts for such a shift in legal thought, specifically, from an ordinary conception of property to a scientific conception. He views the problem posed by use of the ordinary conception in modern constitutional analysis as one of methodology-it is no longer capable of yielding determinate answers about the constitutional protectibility of many private economic interests because social expectations, to which the ordinary conception is tied,

159. Legal Realists of the 1930's and 1940's called for substitution of a "scientific account of legal happenings for the classical theological jurisprudence of concepts." Cohen, Transcendental Nonsense and the Functional Approach, 35 Colum. L. Rev. 809, 821 (1935). To many of them, like Felix Cohen, this meant resorting to statistical methods and other behavorial sciences. 1d. at 833. This scientific methodology would then pave the way for Progressivist law reforms. While Cohen was unusual among the Realists in overtiy linking the "functional approach" of Realism with "ethical criticism of law," there was a distinctly liberal political agenda within the Realist movement. See generally D. Hollinger, Morris R. Cohen and the Scientific 1deal 187-88, 197-98 nn. 66-67 (1975); Note, 'Round and 'Round the Bramble Bush: From Legal Realism to Critical Legal Scholarship, 95 Harv. L. Rev. 1669 (1982).

160. T. Kuhn, The Structure of Scientific Revolutions (1970). 
are clear and well-developed only with respect to interests that manifest themselves in some spatially obvious way. As to more abstract interests, which include government-derived wealth, social expectations are indeterminate.

My objective here has been to show that the problem created by the emergence of newer forms of wealth is not methodological, but moral and political. The revolution in legal analysis and specifically the reconceptualization of property that Ackerman views as imminent is not Kuhnian in nature and is not inevitable. The ordinary mode of legal analysis and the conception of property continue to be capable of resolving the status of threatened interests because that conception is more abstract than he supposes. The conclusion in Flemming $v$. Nestor that the Social Security recipient's interest is not protectible property is not a consequence of its spatial characteristics but of the fact that, according to the terms under which it was created, it is subordinate to a discretionary power of termination. Not only is this conception consistent, at least at an abstract level, with common-law distinctions, but it is also consistent with the tendency in ordinary thought to consider that interests that may be extinguished by another at any time and for any reason have no basis for legitimate expectations of protection. The reaction against this conception and the ordinary mode of analysis may more accurately be explained as an attempt to adjust the conceptual structure of the constitutional property clauses in order to continue to serve dominant liberal values, which would be disserved by adhering to the conventional conception, at least with respect to the new property interests.

There is, then, both continuity and discontinuity between the so-called scientific conception of property that is used in critical work like that of Reich and others and the conception that inheres in common-law distinctions among interests. The discontinuity is methodological, but that is only to say that writers like Reich offer a different conception of property from that used in Flemming and in ordinary culture. Beneath the surface discontinuity, there is a political continuity that provides the impetus for the methodological shift. The political foundations of "the new property" idea are essentially those of the conventional or common-law conception of property, stripped of its formalistic dressing. In assessing the significance of the development that Professor Ackerman describes, attention ought properly to be focused upon the political assumptions of the mode of legal analysis and the conception of property that he sees as mounting a serious challenge to the conventional mode and its conception, for the shift cannot be conveniently justified as necessitated on methodological grounds alone. 